\title{
POETA ENTRE PINTORES
}

\section{Poet among painters}

Un poeta entre los pintores

\section{> Mariorie Perloff [Universidade de Stanford, Estados Unidos] *}

Tradução: Ana Clara Mattoso [Universidade Federal Fluminense, Brasil] * *

Augusto Melo Brandão [Universidade Federal Fluminense, Brasil] ***

RESUMO O ensaio trata da relação entre a obra poética de Frank O'Hara e a pintura, em especial com as vanguardas do expressionismo abstrato na cena artística da Nova York dos anos 1950 e 1960. O texto integra o terceiro capítulo do livro homônimo escrito pela crítica e ensaísta Marjorie Perloff, todavia inédito em língua portuguesa. Analisando as relações de $\mathrm{O}^{\prime} \mathrm{Hara}$ com artistas visuais no plano afetivo, intelectual, profissional e artístico, Perloff enfatiza as experimentações formais desse autor cuja poesia foi diretamente influenciada pela action painting, pelo happening e pela sua atuação como crítico e curador do MoMA. O ensaio apresenta ainda duas colaborações artísticas de O'Hara com os pintores Larry Rivers e Norman Bluhm, que Perloff denomina poemapinturas, dado o entrelugar formal que os caracteriza, poeta e pintor agindo simultaneamente sobre uma mesma superfície. Poesia e pintura revelam-se, na obra de O'Hara, partes de uma mesma matéria vivente. [Resumo e palavras-chave elaborados pelos tradutores].

PALAVRAS-CHAVE Frank O'Hara, Marjorie Perloff, poesia e pintura, literatura em campo ampliado

\footnotetext{
* Marjorie Perloff ministra cursos e escreve sobre poesia e poéticas anglo-americanas dos séculos XX e XXI em perspectiva comparatista, bem como sobre intermídia e artes visuais. É professora emérita de Inglês na Universidade de Stanford e titular da cadeira Florence R. Scott de professor emérito de Inglês na Universidade da Califórnia do Sul.É membro da Academia Americana de Artes e Ciências e da Sociedade Filosófica Americana. E-mail: perloffmarjorie@gmail.com

* * Ana Clara Mattoso é mestranda em Estudos Contemporâneos das Artes pela Universidade Federal Fluminense, cineasta e artista visual. E-mail:anacmattoso@gmail. com, ORCID: https://orcid.org/0000-0003-0813-1040

*** Augusto Melo Brandão é mestrando em Estudos Contemporâneos das Artes pela Universidade Federal Fluminense, performer, escritor, tarólogo e astrólogo. E-mail: cartas.m.b.a@gmail.com, ORCID: https://orcid.org/0000-0003-1894-634X
} 
Citação recomendada: PERLOFF, Marjorie. Poeta entre pintores [tradução Ana Clara Mattoso e Augusto Melo Brandão]. Revista Poiésis, Niterói, v. 22, n. 38, p. 191-245, jul./ dez. 2021. [https://doi. org/10.22409/poiesis. v22i38.50654 ]

Este documento é distribuído nos termos da licença Creative Commons Atribuição-NãoComercial 4.0 Internacional [CC-BY-NC] ( 2021 Marjorie Perloff, Ana Clara Mattoso, Augusto Melo Brandão
ABSTRACT The essay approaches the relations between Frank O'Hara's poetry and painting, especially with the abstract expressionism avant-garde artists in New York scene during the 1950s and 1960s. The text integrates the third chapter of the homonymous book, written by Mariorie Perloff, yet unreleased in Portuguese. Analyzing the relations between $O^{\prime}$ Hara and visual artists from an affective, intellectual, professional and creative perspective, Perloff emphasizes the formal experimentations of the author whose poetry was directly impacted by action painting, happening and his role as art critic and curator at MoMA. The essay presents two artistic collaborations of $O^{\prime}$ Hara with Larry Rivers and Norman Bluhm, referred by Perloff as Poem-Paintings, given their formal in-between space, poet and painter acting simultaneously on the same surface. In O'Hara's lyric, poetry and painting reveal themselves to be, after all, parts from the same living substance. [Abstract and Keywords written by the translators].

KEYWORDS Frank O'Hara, Marjorie Perloff; Poetry, painting, literature in the expanded field

RESUMEN El ensayo trata de la relación entre la poesía de Frank O'Hara y la pintura, sobre todo en lo que respecta a las vanguardias del expresionismo abstracto en la escena artística de Nueva York en los anos 1950 y 1960. El texto forma parte del tercer capítulo del libro homónimo de la crítica y ensayisła Marjorie Perloff, aún no publicado en lengua portuguesa. Analizando las relaciones de O'Hara con artistas visuales en perspectiva afectiva, intelectual, profesional y artística, Perloff subraya las experimentaciones formales de ese autor cuya poesía fue directamente influenciada por la action painting, por el happening y por su actuación como crítico y curador del MoMA. El ensayo presenta aún dos colaboraciones artísticas de O'Hara con los pintores Larry Rivers y Norman Bluhm, que Perloff llama de poemapinturas, debido al entre-lugar formal que los califica, poeta y pintor actuando simultáneamente sobre una misma superficie. Poesía y pintura resultan, en la poética O'Hariana, partes de una misma materia viviente. [Resumen y palabras-clave escritos por los traductores] PALABRAS-CLAVE Frank O'Hara, Marjorie Perloff; poesía, pintura, literatura en campo ampliado 
Às vezes eu penso que "estou apaixonado" pela pintura. [O'HARA, 1971, p. 329]

Em 1965, Francine du Plessix, ao editar uma publicação especial da revista Art in America sobre a relação da poesia com a pintura, fez um convite para que vinte e dois pintores escolhessem um poema contemporâneo que lhes fosse especial e "dedicassem a ele um trabalho em preto e branco produzido no suporte de suas preferências." "A fim de evitar duplicações", ela explica, "eu defini um sistema de escolha por ordem de chegada. Três pintores de Nova York, por exemplo, tiveram que fazer uma segunda escolha porque Frank O'Hara, o poeta que desejavam ilustrar, já tinha sido escolhido por Jasper Johns, o primeiro artista a responder o nosso projeto e a pedir para interpretar a obra de O'Hara'" [DU PLESSIX, 1965, p. 24].

A popularidade de O'Hara entre os principais artistas de sua época é hoje emblemática. Rene d'Harnoncourt, em seu prefácio de In Memory of My Feeling [publicado em 1967, o volume comemorativo deluxe trazia trinta poemas de O'Hara ilustrados por artistas com os quais o poeta mantinha relações extremamente próximas] explica: "Frank nunca precisou ser incisivo porque ele sabia exatamente o que sentia diante de uma obra de arte. Ele cultivava uma integridade absoluta, e nela não havia espaço para presunção... foi através de sua presença que muitos entre nós aprenderam formas melhores de enxergar²". Naturalmente, as trinta ilustrações do livro variam em termos de qualidade, estilo e adequação ao poema em questão, no entanto, quando apreendidas como um todo, não falham em transmitir um testemunho eloquente da relação extraordinária que O'Hara nutria com pintores tão diversos como Larry Rivers, Robert Motherwell, Jasper Johns, Graça Hartigan, Barnett Newman, Robert Rauschenberg, Alfred Leslie, Norman Bluhm, Joe Brainard, Helen Frankenthaler e Willem de Kooning. Desde o início dos anos cinquenta, tempo em que vendia cartões de Natal na recepção do Museu de Arte Moderna de Nova York, até o ano de sua morte, momento em que, como curador, começou a trabalhar numa grandiosa retrospectiva das obras de Jackson Pollock e finalmente havia garantido o consentimento de De Kooning para organizar uma relevante coletânea de sua trajetória na pintura, O'Hara trabalhou em estreita colaboração com muitos desses artistas, organizando suas exposições, visitando seus ateliês, entrevistando-os e escrevendo sobre seus trabalhos. Muitas das parcerias [poemapinturas e suas respectivas performances em suportes variados] desenvolvidas a partir dessas conexões, são, em sua própria essência, 
importantes obras de arte - mesmo que os críticos literários tenham a inclinação de ignorá-las. Retornaremos a elas nos próximos tópicos deste texto.

Costuma-se argumentar que as artes visuais tomaram muito tempo de O'Hara, impedindo-o de se dedicar àquilo que seria sua verdadeira vocação - a poesia. John Ashbery, por exemplo, aponta:
[...] ele odiava ficar longe de Nova York e de todos os seus amigos, odiava ter que retornar aos mesmos cenários dos seus anos de faculdade, e enquanto esteve em Massachusetts não escreveu nenhuma dramaturgia, apenas alguns poemas. Assim que se liberou, voltou para Nova York num surto, bebeu mais do que eu jamais o vira beber e ficava o tempo todo falando como Cambridge era provinciana [...]. Nitidamente Frank não se encaixava no perfil dos editais para os quais ele nem sequer se candidatou, nem em lugares como Yaddo, onde Há momentos em que queria que ele não tivesse se envolvido tão fertilmente com - Museu e o mundo da arte. Ao contrário da maioria dos artistas que ilustrou o seu livro, por mais que Frank fosse um poeta aclamado internacionalmente, as dinâmicas econômicas do mundo da arte não permitiam que ele se sustentasse exclusivamente do seu trabalho. Isso significa que ele nunca poderia se dedicar à poesia por mais do que uma fração de seu tempo ${ }^{3}$. [ASHBERY, 1968, p. 68] ele nunca colocou os pés; eu acho que ele via nesses espaços algo como a criação de situações artificiais para a escrita. Mas me parece que a disposição do Museu funcionou para ele. Não que a rotina e o trabalho burocrático fossem uma fonte de prazer, na verdade, muitas vezes tudo isso fazia com que ele chegasse à beira do colapso; era simplesmente uma questão de, quem sabe, precisar da concretude e disciplina do mundo regrado do trabalho diário [...]. E, acima de tudo, ele acreditava no que estava fazendo. Para ele, não se tratava apenas de um trabalho, era uma necessidade vita ${ }^{4}$.

pir palavras. Entretanto, do mesmo modo que Williams, a quem ele se assemelha em tantos aspectos, O'Hara se apropriava - e, mais do que isso, precisava - deste outro ofício como fonte de inspiração. Como relembra Joe Le Sueur, o único período no qual O'Hara se absteve do Museu [janeiro a junho de 1956] em decorrência de um prêmio relativo ao Poet's Theatre em Cambridge, Massachusetts, acabou se transformando "num verdadeiro inferno para ele":
O Museu, portanto, serviu a O'Hara como um point de repère, um centro sólido e estável cuja rotina das nove às cinco oferecia um contrapeso ao seu estilo de vida libertário e desorganizado. Mas até mesmo as famosas noitadas de muito álcool e conversação - fossem elas no Cedar Bar ${ }^{5}$ ou nas festas de Long Island - cumpriam uma importante função na vida do poeta. Como LeSueur constata: 
[... ele parecia inspirado e eletrizado por todos os seus amigos pintores, desde Bill De Kooning, a quem idolatrava, até outros nomes que surgiram nos anos 60, como Alan d'Arcangelo. Era tão grande o tempo que dedicava para olhar e refletir sobre esses trabalhos que você pensaria que o que existia ali era um forte interesse no desenvolvimento deles enquanto artistas. Mas eu não compactuo inteiramente com essa ideia sugerida por vários amigos de Frank, de que sua generosidade o afastou de seu próprio trabalho. Não foi exatamente isso o que aconteceu. Ele ofereceu-Ihes encorajamento, inspirou-os com suas ideias e sua paixão; eles, por sua vez, colidiram e adentraram em sua poesia, que, sem essa interferência, não teria sido a mesma e provavelmente não seria tão boa. ["Four Apartments", p. 292] e serigrafias menores e maiores, espalha-se por cima e ao redor da figura nua reclinada do poeta [Fig. 1], palavras são atiradas sobre formas sugestivas e semi-abstratas em suas estonteantes Sua poesia, sem dúvida, não teria sido a mesma. Em primeiro lugar, os pintores e a pintura alimentaram O'Hara com um de seus temas centrais.

Considere Graça Hartigan, cuja vida esteve extremamente conectada à de Frank no início dos anos 1950 até $1960^{6}$, e o papel desempenhado por ela nos poemas. Na opinião da pintora, ela e o poeta muitas vezes se apropriavam da mesma imagem como ponto de partida. Assim, quando Graça Hartigan pintou Oranges / Laranjas, a série correspondente aos doze pastorais de mesmo nome que O'Hara havia escrito poucos anos antes, ela encontrou as formas mais engenhosas de aplicar as palavras do poeta: algumas vezes, amontoando um poema inteiro em um canto da tela, outras, no objetivo de criar fortes camadas de tensão e êxtase, espalhando apenas algumas palavras pela superfície. Como acontece em What Fire Murmurs Its Sedition, onde todo o terceiro poema em prosa de $\bigcirc$ 'Hara, fragmentado em texto corrido cores brilhantes. É interessante notar como o poeta e a pintora abordam de maneiras semeIhantes a palavra oranges: exceto pelo título, O'Hara nunca a menciona; já em Hartigan, a cor é usada apenas ocasionalmente, não sendo de forma alguma proeminente em sua série.

Neste caso, então, a poesia inspirou a pintura. Mas a recíproca também é verdadeira. Graça [o nome carrega, obviamente, infinitas leituras] aparece numa sequência de poemas, começando com o soneto de amor inicial, Poem for a Painter/ Poema para um pintor ${ }^{7}$, no qual o interlocutor declara:

\section{Graça,}

você é a florista na campina à luz de velas

os dedos encharcados de aguarrás ${ }^{8}$

[O'HARA, 1971, p. 80] 


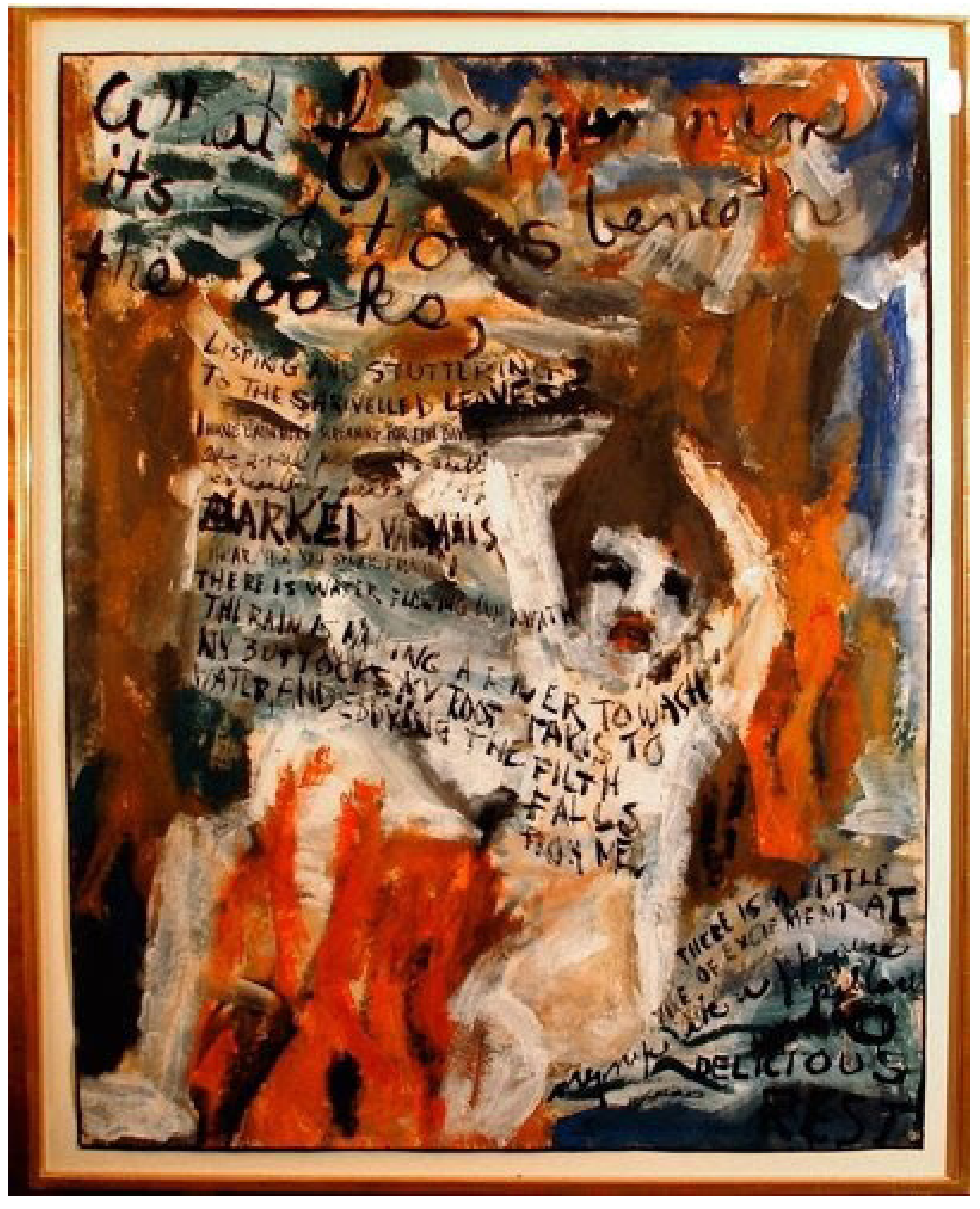

Fig. 1. Graça Hartigan. What Fire Murmurs lts Sedition / Que fogo murmura sua revolta. 1952. Óleo em papel, $48 \times 38$ polegadas. No. 3 da Série Oranges.

Coleção Leonard Kasle. 
É bastante evidente que O'Hara encontrou na pintura de Graça a confirmação visual de sua própria estética; vejamos as observações descritas pelo autor no ensaio de 1954, Nature and the New Painting:

O início de sua carreira foi como uma pintora abstrata [...]. Seus primeiros trabalhos mostram a influência dos ensinamentos de Hans Hofmann e do espírito livre e iconoclasta de Jackson Pollock. Dizem que, numa manhã, ela acordou com a decisão de que não poderia mais continuar a pintar abstratamente. [...] Deixando para trás as preocupações de origem exclusivamente estética sobre suas abstrações, as novas telas convulsionam imagens e influências até então reprimidas: nus fantásticos e figuras fantasiadas, naturezas mortas densas como pedreiras, referências abertas aos monumentais banhistas de Cézanne e Matisse. [...] Uma pintora, fundamentalmente, de quadros heterogêneos, onde o agrupamento de imagens extremamente dissonantes se conjura através do insight sobre as relações funcionais que mantém... seu método é realçado quando aproximado, por exemplo, de um pintor abstrato como Philip Guston, cujos vários períodos e explorações culminam no silêncio puro, integral e perfeito, de seu presente trabalho. [O'HARA, 1975b, p. 44-45, grifos da autora]

Aquilo que O'Hara chama de "inclusão progressiva" na obra de Hartigan se transmite de forma belíssima na seguinte passagem de Second Avenue / Segunda
Avenida, que segundo o poeta é: "uma descrição da pintura de Graça Hartigan” [O'HARA, 1971, p. 486].

\section{Graça devora}

os rostos rodopiando em desafinado desbunde ali onde ansioso,

o nariz arrebitado para os céus em carrossel de risadas

e obliterado espasmodicamente com nacos de gorda tinta branca e isso é amor para ela, é o que eu desejo

e que você, para que possa jogar fora uma coisa sem bocejar

"Ah Folhas de Relva! Ah Sylvester! Ah Conferência das Bordadeiras"

e assim cumprir a nossa promessa de destruir alguma coisa mas não a gente 9

$$
\text { [O'HARA, 1971, p. 149] }
$$

Perceba como as imagens heterogêneas e os deslocamentos sintáticos de O'Hara "mimetizam" o próprio processo de pintura. O pronome "onde" ["onde ansioso"] não tem antecedente; "em carrossel de risadas" nenhum referente específico e, ainda assim, descobrimos que "isso" ["desafinado desbunde"? Os "céus" vistos como um "carrossel"? Os "nacos de gorda tinta branca"? Ou todas essas coisas juntas?] torna-se "amor para ela" e também é "o que eu [o poeta] desejo". Na linha 6, a frase abreviada "e o que você" desloca novamente a perspectiva: nesse momento, "você" se transforma na própria Graça; sua pintura é tudo o que ela deseja que seja - uma 
estrutura de "imagens extremamente dissonantes" que, de alguma forma, conseguem escapar à grandiloquência ["Ah

Folhas de Relva! Ah Sylvester! Ah Conferência das Bordadeiras], sendo capazes de desfigurar ["jogar fora uma coisa sem bocejar"] a pura abstração em privilégio da heterogeneidade - "Imagens [...] até então reprimidas ", "pinceladas caóticas e redemoinhos de impasto" [O'HARA, 1975b, p. 45] - nutrida pela paixão pessoal ["e assim cumprir a nossa promessa de destruir qualquer coisa mas não a gente"].

Em poemas de amor tão agridoces ${ }^{10}$ quanto Christmas Card for Grace Hartigan | Cartão de Natal para Graça Hartigan [O'HARA, 1971, p. 212] e For Grace, after a party / Para Graça, depois de uma festa [O'HARA, 1971, p. 214], O'Hara deixa que uma imagem "sangre" na outra, espelhando a técnica que Hartigan executa na pintura. "Estenda sua mão", diz ele neste último, "não há / um cinzeiro, de repente, ali? Ao lado / da cama?". Ou ainda, em meditações sobre a condição da identidade, a capacidade de assumir diferentes papéis e cultivar "referências sórdidas", emerge no consagrado In Memory of My Feelings / À memória de meus sentimentos [1956], dedicado a Graça Hartigan, a aforística frase: "a graça / de nascer e viver de tantos modos quanto possíveis". "Esta menção à "graça", segundo o que a própria pintora me disse, relaciona-se às linhas precedentes:
O'Hara, nesse ponto, evoca dois nus artísticos de Hartigan ${ }^{12}$. Até mesmo as figuras das pinturas de Graça parecem ser fruto de identificação para ele, que adentra, por assim dizer, no universo de suas telas. Talvez em L'Amour avait passé par là ${ }^{13}$ [1950] se encontre o melhor exemplo sobre a importância da relação afetiva com Graça Hartigan na construção dos poemas. Nesse poema, o eu lírico aparece como um Pierrot que lamenta a perda de seu amor. A mudança de tom entre o humor gentilmente triste e autodepreciativo e a consolação se traduz, sobretudo, em imagens da arte. Assim começa o poema:

Sim

como o centro silencioso de um livro sobre Joan Miró azul vermelho verde e branco...

e o gigantesco espelho atrás de mim pisca, manchado de tinta eles pintaram o teto do meu coração

e penduraram uma nova luminária

e Arte Contemporáneo por Juan Eduardo Cirlot e o Petit Guide para o Museu Nacional Russo... 
Falta pouco para o poeta se transformar na página em branco de um livro de arte. De repente ele se lembra que deve "ir ao Cedar para encontrar Graça”, e assim, com uma sublime ostentação de lógica, declara:

\section{Preciso apertar meus mocassins}

e esquecer as bibliografias miúdas de decepção

angústia e poder

em troca da honestidade tensa...

E a "honestidade tensa" de seu tête-a-tête com Graça pode levá-lo a novos limiares:

uma vela mantida próxima à janela tem duas chamas

e talvez um bando de seguidores no sereno da juventude

assim como debaixo do arco você encontrará um coração de batom ou uma camisinha deixada pelo desfile

de uma intuição generalizada

é o grande período da arte italiana quando todo mundo imita Picasso

com medo de significar qualquer coisa

enquanto a segunda chama em seu reflexo feliz ignora a vela e o vento

[O'HARA, 1971, p. 333]
Aqui, contrapondo a pálida "luminária" suspensa anteriormente do coração do poeta, Graça é associada à "segunda chama" com seu "reflexo feliz". A segunda estratégia de O'Hara para fundamentar e autenticar um estado de espírito singular em seus poemas sobre arte é evocar artistas ou obras de arte como marco referencial. Isso acontece em Having a Coke with you/ Tomar uma coca-cola com você[1960], quando o poeta faz uso do humor para mostrar a superioridade daquele que ama [Vincent Warren] diante das obras O Cavaleiro Polonês de Rembrandt, Nu Descendo uma Escada de Duchamp e das figuras equestres de Marino Marini, que de alguma forma no que considero uma percepção sagaz - não são

capazes de escolher "o cavaleiro com o mesmo cuidado que o cavalo" [O'HARA, 1971, p. 360]. Em A Warm Day for December / Um dia quente para Dezembro[O'HARA, 1971, p. 375], ao percorrer as galerias da 57th Street, o poeta observa que está "Isolado pelo meu novo corte de cabelo / e parecendo mais com Brancusi que de costume". Ou então vejamos Rádio, escrito em 1955 : 
Por que você toca essa música deprimente

no sábado à tarde quando cansado, não,

exausto, eu anseio por uma pequena

lembrança da energia imortal?

A semana

inteira enquanto me arrasto com dificuldade

entre as escrivaninhas do museu

você solta os seus milagres de Roxette

e Tears for Fears por essas prisões.

Não estou eu

também trancado, e depois de uma semana

de trabalho não mereço George Michael?

Bem, eu tenho o meu belo de Kooning

em quem me inspirar. Penso que dentro dele existe uma

cama laranja, mais do que o ouvido pode ter ${ }^{14}$.

[O'HARA, 1971, p. 234]

É na cômica inversão dos três últimos versos, com a lógica aparentemente absurda de que o poeta não precisa de música porque seu «belo de Kooning" Ihe oferece "mais do que o ouvido pode ter" que reside o charme do poema. Mas é óbvio que O’Hara não está brincando: diferente de afastá-lo dos prazeres da música, estar «isolado» no museu fez com que aprendesse a «escutar» as pinturas. Todas as artes - visuais, sonoras, escritas - são interdependentes. Como sugere o poema, aperfeiçoe uma e as outras estarão cada vez mais próximas. Muito longe de ser um comentário aleatório, a referência de O'Hara à obra de De Kooning se baseia em fatos reais, e isso é o que a torna particularmente interessante. Certamente, uma das potências singulares em O'Hara é a maneira carinhosa com que apreende os detalhes reais responsáveis pela transmissão de autenticidade. Em uma carta enviada a Frank em 22 de março de 1956, Kenneth Kock endossa:

Rádio é impecável. Ontem à noite eu estava na Cedar Tavern e Bill de Kooning estava lá, então the perguntei se já tinha lido o seu poema sobre a tela dele. Ele respondeu, Já. . . mas como posso ter certeza de que é sobre a minha pintura, ou se é apenas sobre uma pintura qualquer? Eu citei "eu tenho o meu belo de Kooning / em quem me inspirar. Penso que dentro dele existe / uma cama laranja ...." Ele retrucou: "É um sofá. Mas isso é incrível, a pintura então é realmente a minha." E assim começou a me contar que sempre se interessou por colchões porque, "como a terra", eles se unem em alguns pontos e se expandem em outros. [O'HARA, 1971, p. 536]

Com o desejo de "traduzir" a atmosfera da pintura em um suporte verbal, outro grupo de poemas inspirados pela arte pode ser classificado como 
meditações sobre pinturas específicas. Ao contrário dos trechos de Second Avenue / Segunda Avenida e In Memory of My Feelings / À memória dos meus sentimentos discutidos acima, esses são poemas que abordam a pintura como um tema independente, sem referência ao artista. Poem [The eyelid has its storms] / Poema [A pálpebra tem seus temporais...], por exemplo, tenta capturar o que O'Hara chama de "tragédia de uma violência linear" [O'HARA, 1975a, p. 33], em seu ensaio sobre a obra de Jackson Pollock. 0 poema começa assim:

A pálpebra tem seus temporais. Primeiro o seu verde opaco, escama de peixe após nadar no mar e de repente a a violência arranca, cilios estrangulados, e um arame farpado de areia despenca na beira da praia ${ }^{15}$.

[O'HARA, 1971, p. 223]

Enquanto comentário sobre uma das all-over paintings de Pollock, este é um poema eficaz, mas fico me perguntando se ele se sustentaria para além desse fato. Também tenho minhas reticências em relação à Blue Territory'16 / Território Azul, que com esse nome, se torna um poema "sobre" a pintura de Helen Frankenthaler. Novamente aqui, a interpretação de O'Hara se torna interessante para alguém que já sabe que tal pintura abstrata, com suas formas curvilíneas, cores vibrantes e superfícies cintilantes carrega sutis lembranças de uma paisagem oceânica.

Grandes sacos de areia até eles chegarem, o lisonjeiro fim

do mundo

as gaivotas estavam mergulhando e engolindo e enchendo os sacos

como criaturas prestativas por toda parte ajudavam a acabar

o mundo

então nós podíamos ficar a sós finalmente, um por um quem precisa de uma arca?...

[O'HARA, 1971, p. 270]

Mas se isolarmos esse tone poem ${ }^{17}$ impressionista e olharmos só para ele, sua "pintura" falha em ganhar corpo. Escrito em 1955, Joseph Cornellé uma "tradução" mais fortuita da pintura em poesia. Cornell foi um mestre da assemblage surrealista; suas intrigantes caixas de sombra acoplavam palavras e imagens exóticas a objetos banais dedais, cascas de ovo, espelhos e mapas - a fim de criar pitorescas fábulas do inconsciente. Um bom exemplo é Taglioni's Jewel Casket [1940], adquirida 
pelo Museu de Arte Moderna de Nova York. Contendo quatro fileiras de cubos de vidro, a caixa é feita de madeira, veludo, vidro e plástico. Dentro do revestimento coberto por veludo azul, encontramos um papel branco com a seguinte "mensagem": "Em uma noite de luar no inverno de 1835, um salteador russo bloqueou a carruagem de Maria Taglioni e ordenou à tão encantadora criatura que dançasse para ele, público de apenas um, por cima da pele de pantera que cobria o gelo sob as estrelas." Tal caixa, combinando espaço tridimensional e ilusão cênica, torna-se, nas palavras de William Rubin ${ }^{18}$, uma espécie de "teatro espacial". A solene narrativa sobre Madame Taglioni se justapõe, de maneira engenhosa, à simples caixa prosaica com suas fileiras compostas por blocos de vidro aritmeticamente posicionados. O'Hara transmite algo equivalente às caixas de Cornell em seu poema:

\section{Sobre um desastre deslumbrante,}

meticulosamente detalhado, a luz violeta irradia. Não é um céu, é um quarto. E no campo aberto uma taça de absinto vibra uma canção indiana. Ventos das pradarias circundam mesquitas.

Você é sempre jovem demais para entender. Ele está cansado com seu sentido do passado o artista. Para fora da profética rocha em seu peito ele espalhou um solo sem flores de forração.

[O'HARA, 1971, p. 237]
Aqui, há uma a proximação sensível das experiências verbais e visuais. Na primeira "caixa", o poeta concede sua versão às "mensagens" de Cornell como uma descrição exótica e estilizada que rememora a passagem de Maria Taglioni. Numa mudança abrupta, a segunda "caixa" persegue a reação do espectador, o "você" [todos nós] que é "sempre jovem demais para entender". Assim como faz Cornell, o artista deve criar novas formas porque "Ele está cansado com seu sentido do passado o artista". De maneira aforística, a terceira sentença converge para o espírito da arte de Cornell: "ele espalhou um solo sem flores de forração" [aqui, até mesmo a quebra de linha enfatiza a ausência], a "coisa nua e crua", como diria Wallace Stevens, se esgueirou "para fora da profética rocha".

Certamente, mesmo nesse caso a compreensão do poema de O'Hara depende que conheçamos pelo menos um pouco da obra de Cornell. Em algumas situações, no entanto, quando O'Hara trabalhava numa colaboração extremamente próxima com pintores específicos, a aura da pintura era absorvida tão intensamente pelo poema a ponto de libertá-lo. Acredito que isso se concretize em On Seeing Larry Rivers' Washington Crossing The Delaware at the Museum of Modern Art / Depois de ver Washin- 
gton Crossing the Delaware, de Larry Rivers, no Museu de Arte Moderna ${ }^{19}$ [O'HARA, 1971, p. 233]. Em uma entrevista com O'Hara para a revista Horizon em 1959, Rivers explica o que tentava elaborar nesta pintura em particular:

\section{[...] $\bigcirc$ que poderia ser mais ridículo do que uma pintura} homenageando um clichê nacional como Washington Crossing the Delaware. A última pintura sobre George e os rebeldes, pendurada na parede do Met, foi pintada pelo dono da maior paixão por Napoleão já vista, um acadêmico alemão tosco do século XIX, que acreditava que um general cruzando um rio numa tarde qualquer do final de dezembro era só mais um pretexto para exercer aquela pose heróica, ligeiramente trágica. . . Quanto a mim, o que vi nessa travessia foi outra coisa. Eu vi tensão e desconforto nesse momento. Para mim era impossivel imaginar que qualquer pessoa entrando num rio gelado perto da época do Natal pudesse estender heroicamente a mão no peito. [O'HARA, 1975a, p. 112]

"Como as pessoas reagiram ao verem George?" pergunta O'Hara. "Praticamente da mesma forma", Rivers responde, "que reagiram numa exposição Dada em Zurique, quando os Dadaístas trouxeram um assento de vaso sanitário como peça de escultura. A diferença é que não causou perturbação no público - só nos pintores. Fui chamado de impostor pelo pintor Gandy Brodie, que foi bem enérgico em sua consideração. No bar que eu frequento, vários pintores fizeram piada" [O'HARA, 1975a, 113].

Por outro lado, o próprio ○'Hara compreendeu a pintura de Rivers perfeitamente. Escrito em 1955 , seu poema aborda Washington's Crossing of the Delaware com irreverente e jocoso desdém.

Agora que o nosso herói voltou pra gente em suas calças brancas e conhecemos seu nariz sacudindo como uma bandeira num tiroteio,

vemos que o rio calmo e gelado apoia

nossas forças, bela história ${ }^{20}$

[O'HARA, 1971, 233]

As quatro estrofes seguintes continuam a dar ênfase à situação absurda que O'Hara, assim como Rivers, considera como um não-acontecimento: uma "travessia pela água, no inverno, para uma margem que não é a mesma alcançada pela ponte." Aqui, a rima infantil - shore/ reaches for - ressalta o bathos do que se entende por nossa "bela história" - note que a travessia ocorre em um "brilho enevoado". Com um discurso satírico endereçado a George, o poema termina culminando no trocadilho com a palavra "general" [general fear]. 
Não atire até que, o branco da liberdade brilhando no cano da espingarda, você veja o medo em todos.

[O'HARA, 1971, 234]

Embora o poema de O'Hara seja especialmente sagaz quando lido em conjunto com a pintura de Rivers, compreendê-lo como a reescritura de um dos grandiosos eventos na história dos Estados Unidos - uma visão irônica do "Querido pai de nosso país" com "seu nariz/ sacudindo como uma bandeira num tiroteio" - também pode acontecer de forma independente.

Seja com sua resposta poética à pintura de Larry Rivers, ou na celebração lírica de Graça Hartigan, O'Hara parecia sentir-se mais à vontade com pinturas que guardavam pelo menos algum resquício figurativo do que com a pura abstração. Pollock, Kline e Motherwell podem até ter sido os grandes ídolos de O'Hara, mas, em termos práticos, era complicado, por exemplo, transportar a total abstração de Blue Territoryem Frankenthaler para a poesia. De um jeito ou de outro, as palavras carregam significados, e no fim das contas as implicações temáticas sempre arrumam um jeito de se anunciar. No próximo capítulo, quando abordaremos os poemas mais emblemáticos de O'Hara, veremos que o poeta empregou alguns dos maiores conceitos do Expressionismo Abstrato, tais como o push-and-pull; a pintura all-over-onde a composição aparece como um continuum sem fim ou começo -; e a famosa observação de Harold Rosenberg de que, na Action Painting, a tela deixa de ser espaço de reprodução para se tornar uma arena sobre a qual agir. Como poeta, no entanto, O'Hara demonstra certa ambivalência em relação aos grandes nomes do Expressionismo Abstrato, ambivalência que produz tensões interessantes em sua crítica de arte, ponto sobre o qual me debruçarei a seguir.

\section{SENTADO EM UM CANTO DA GALERIA}

- Eu visto pano oleado e leio música

no candelabro de barro de Guillaume Apollinaire ${ }^{21}$.

[O'Hara, 1971, p. 18]

Quando se trata de seu trabalho como crítico, surpreendentes pontos de encontro podem ser traçados entre O'Hara e o seu maior herói, Guillaume Apollinaire 22 . LeRoy Breuning, na introdução à coletânea de poetas franceses na crítica de arte, escreve: "O dom que Apollinaire possuía, sua intuição, seria capaz de provocar inveja na maioria dos críticos profissionais. Ele sabia como reconhecer uma grande obra quando via uma. Dentre o enxame de pintores desconhecidos nos salões e galerias de 
sua época, ele conseguia reconhecer, através de um olhar apurado e de sua fé na 'nobreza' da arte, aqueles que estavam destinados a perdurar". ${ }^{23} \mathrm{Em}$ sua resenha do Salon d'Automne de 1911, o primeiro Salon em que participam os cubistas, encontramos um bom exemplo da abordagem pouco ortodoxa de Apollinaire na crítica de arte: "Na minúscula Sala 8 encontram-se as obras de alguns pintores conhecidos como cubistas. Contrariando o senso comum, o cubismo não se trata da arte de pintar tudo e qualquer coisa na forma de um cubo" [APOLLINAIRE, 1971, p. 183]. Depois de fornecer um breve histórico sobre as primeiras pinturas cubistas de Picasso e a relação entre o Cubismo e o Fauvismo, Apollinaire tece um comentário perspicaz: para 1911, nós sabemos como essa declaração foi profética. As mesmas características podem ser encontradas na crítica de arte de O'Hara: ausência de discurso teórico - e, exceto em alguns casos, de análise técnica rigorosa - contrabalançada pela fantástica capacidade de reconhecer grandeza e de distinguir entre aquilo que é incomparável e o que é quase tão bom quanto. Da mesma forma que acontecia com Apollinaire, O'Hara possuía a astúcia inata de reconhecer de prontidão a pintura ou as pinturas que se destacariam em meio a grandes mostras coletivas instauradas em galerias.

Em nenhum lugar este caráter peculiar se manifesta de forma mais evidente do que nas três Art Chronicles que O'Hara escreveu em 1962 e 1963 durante

Num primeiro momento, o público, no entanto, acostumado do jeito que estava aos borrões brilhantes, todavia quase disformes, das pinceladas impressionistas, se recusou a reconhecer a magnitude das concepções formais dos cubistas. As pessoas se chocaram com as formas escuras e os segmentos luminosos contrastados, porque já estavam com um olhar totalmente domesticado às pinturas sem sombras. No surgimento monumental de composições que vão além das superficialidades da arte contemporânea, o público se negou a perceber o que realmente estava lá: uma arte nobre e comedida, preparada para dar conta da vastidão temática sobre a qual o impressionismo deixou seus pintores totalmente desprevenidos. Quer as pessoas gostem ou não, o cubismo é uma reação necessária que fará com que grandes obras sejam criadas. [APOLLINAIRE, 1971, p. 183]

Mesmo que Apollinaire não nos forneça nenhuma teoria da pintura Cubista ou uma análise prática de trabalhos individuais, hoje, olhando em retrospecto o período que foi editor de arte da revista Kulchur. Analisando a retrospectiva de Mark Tobey no Museu de Arte Moderna em sua terceira Chronicle, O'Hara conclui: "à sua maneira, Tobey criou coisas ótimas... mas da mesma forma que Redon jamais será comparável a Renoir, elas nunca serão mais que isso ... Não enquanto Willem de Kooning e Barnett Newman estiverem dando pinta por aí". ${ }^{24}$ 
Certamente esta é uma sentença válida. Hoje em dia, é difícil escutarmos o nome de Tobey, já De Kooning segue a pleno vapor, sendo, quiçá, cada vez mais reconhecido como o maior dos pintores de sua época. Na mesma Chronicle, O'Hara menciona Andy Warhol e Robert Indiana - artistas da Pop Art que "tendem a extrair sua arte da vulgaridade [no sentido cotidiano] de objetos, imagens e emblemas" - diferenciando-os de Claes Oldenburg - que "com a ajuda de papel machê, tecido, madeira, cola, tinta e quaisquer outros materiais que possam estar dentro ou acima de suas esculturas, transforma os próprios objetos e emblemas em arte" [O'HARA, 1975b, 141]. Sob a luz privilegiada do afastamento temporal que o final dos anos 70 oferece sobre

o movimento da Pop Art, tal distinção entre o que poderíamos chamar de Pop Artcomercial e o brilhante ilusionismo de Oldenburg com seven-foot pistachio icecream cone ou monstrous wedge of chocolate and vanilla layer cake parece se tornar ainda mais valiosa. flat sculptures realistas eram pintadas, por assim dizer, na contramão das tendências estilísticas de sua época ${ }^{25}$. O'Hara percebeu que as "figuras pintadas em escala não tradicional", "ao enfatizarem, de maneira quase inconsciente, a ausente espacialidade que as permeia, são modernas em seu ethos [...] sem jamais serem silhuetas, não deixam de emitir um certo ar onipresente" [O'HARA, 1975b, p. 136] Publicada na edição de Art Chronicles do verão de 1962, essa observação sobre o trabalho de Katz ganha corpo em um dos melhores ensaios críticos de O'Hara, Alex Katz, escrito para a Art and Literature pouco antes de sua morte. O mundo pictórico de Katz é definido por ele como
Os grandes nomes do Expressionismo Abstrato costumavam ocupar o lugar de protagonistas nas Art Chronicles, mas como O'Hara sempre se importou mais com indivíduos do que com movimentos, ele foi um dos primeiros críticos a reconhecer a singularidade de Alex Katz, cujas "um 'vácuo' de cores pintadas suavemente [...] onde as figuras bastante reais existem [mas não repousam] em um espaço sem chão, sem paredes, sem fonte de luz, sem perspectiva [...]. Em Katz, as pessoas simplesmente existem em algum lugar. Elas permanecem nos retratos não por questões existenciais ou por desorientação, mas como soluções de um problema formal [...]. Sem que pareça existir uma razão ou intenção aparente para que habitem seus quadros, elas configuram um mistério de origem totalmente pictórica. Elas sabem que estão lá." [O'HARA, 1975a, p. 145] 
fervorosos que a versão mais incisiva de O'Hara se manifeste em suas Art Chronicles. Por exemplo, a exposição Abstract Expressionists and Imagists organizada pelo Guggenheim em 1962 e concebida, evidentemente, como uma grande miscelânea, na concepção de O'Hara se deu como "uma situação efervescente", cuja "imperativa indeterminação" "te deixa querendo ver mais" [O'HARA, 1975b, p. 128]. Mas em sua ânsia pela previsibilidade, o público de arte não foi capaz de conter a indignação. dispensasse o seu filho das horas de castigo depois da aula, porque ela queria levá-lo à exposição de Manet. "Paris inteira", disse a senhora, "está marcando presença para rir de suas pinturas. Se meu filho for privado de um entretenimento como esse, que, além de tudo, tem uma função educativa no desenvolvimento de seu bom gosto, nunca conseguirei me perdoar". Foi assim que Mallarmé dobrou a punição. "É nítida a prudência", conclui Apollinaire, "que se deve tomar antes de sair vociferando julgamentos precoces. Errar é tão fácil; e não é "Infelizmente, muitas pessoas queriam se ver legitimadas por uma justificativa, embalada em um novo container da Sherry, que atestasse: 'essa mostra permite que você continue a admirar a pintura abstrata'. Prova disso são as críticas sobre a qualidade da exposição - algumas delas beirando a histeria - que - Guggenheim tem recebido: "COMO ELES OUSAM! UM HOFMANN EM SEU PIOR!" Parece que nenhum dos críticos pensou: "Como ele ousou!" [O'HARA, 1975b, p. 128].

Uma deflação tão espirituosa como essa é típica de O'Hara. Para encerrar, ele lança o golpe final perfeito: "Muita gente amaria ver a arte morta e acabada, mas elas não estão sendo vistas lendo latim lá no Cloisters". Em seu cômico, porém assumidamente maldoso ataque aos dois grandes críticos de arte de sua época, John Canaday e Emely Genauer ${ }^{26}$, O'Hara rememora o irônico ensaio Watch Out for the Paint! de Apollinaire, onde o poeta conta a anedota sobre a senhora burguesa que se endereçou a Mallarmé, então professor de liceu, implorando que todo dia que um Mallarmé vai aparecer para duplicar a punição que uma risada profana merece". ${ }^{27}$

O'Hara, assim como Apollinaire, sempre tentava combater a "risada profana", evidenciando a mente fechada dos resenhistas e o desdém dos críticos. Contrastar o pano de fundo de Apollinaire com a crítica de arte de O'Hara se torna especialmente útil porque nos ajuda a compreender o que ele não era e quais exigências não podemos fazer às suas resenhas, ensaios e catálogos de museus. Com a publicação do Art Chronicles em 1974, vários resenhistas reclamaram que O'Hara era um crítico muito "subjetivo" e "impressionista", que não ofereceu ao movimento ${ }^{28}$ do Expressionismo Abstrato nenhum pensamento genuíno, tendo 
simplesmente adotado para si a perspectiva já corrente de teóricos como Harold Rosenberg.

Essas reduções não estão totalmente erradas. A versão mais fraca de O'Hara aparece quando tenta conceitualizar sobre abstrações como Arte, Beleza, Realidade ou Natureza. Nature and the New Painting [1954], um de seus primeiros ensaios, oferece uma amostra interessante dessa interseção, porque ilustra tanto os momentos radiantes do poeta quanto suas fraquezas como crítico. Grande parte deste ensaio é composta por descrições específicas sobre o trabalho de Graça Hartigan [citado anteriormente neste capítulo], Robert di Niro e Larry Rivers, e as contribuições de O'Hara a respeito de suas obras podem ser aplicadas de maneira consistente. Já quando aborda "natureza", as palavras ficam mais nebulosas. Ele diz, por exemplo: "Nos tempos passados existia a natureza e a natureza humana; diante da ferocidade da vida moderna, humanidade e natureza se tornaram uma única entidade [...]. Percebemos nas abstrações e figuras femininas de Willem de Kooning estruturas de um rigor clássico: as identificações inexoráveis entre humanidade e natureza. Isso não é simbólico. Isso está pintado" [O'HARA, 1975b, p. 42]. Consequentemente, a natureza é absorvida tão integralmente pela pintura na arte expressionista abstrata que a tela se torna a união perfeita das duas. Uma ou duas páginas depois, porém, O'Hara explica como a abstração foi deixada de lado por Graça Hartigan para "retornar à natureza" - isto é, às imagens figurativas - uma mudança de estilo que "introduziu uma paixão que aparecia apenas de relance em seus primeiros trabalhos" [O'HARA, 1975b, p. 45]. Mas, se é disso que se trata, onde vai parar a integração perfeita entre arte e natureza nas abstrações de Kooning?

Na pioneira e quase sempre brilhante monografia sobre Jackson Pollock, encontram-se generalizações praticamente tão questionáveis quanto. Contrapondo o cubismo e o surrealismo - "O Surrealismo explodiu aquilo que o Cubismo conseguiu apenas minar"; "O Cubismo foi uma revolução, o surrealismo um aperfeiçoamento" -, O'Hara declara: "Junto da libertação, o surrealismo impôs a responsabilidade de dizer o que você quer dizer e de querer dizer o que você diz, para além de qualquer apego pela fala ou pelo significado" [O'HARA, 1975a, p. 18]. Mesmo que pareça profundo, o que O'Hara realmente está dizendo? Ele parece sugerir que, em algum nível, o Surrealismo é mais literal do que outras escolas de arte, contudo, os próprios surrealistas viam no seu trabalho o extremo oposto: a corporificação dos sonhos, alucinações, imagens inconscientes - a arte da associação livre e dos significados eróticos ocultos. 
Desse modo, a importância de O'Hara como crítico de arte não desponta a partir de seus ensaios formais ou set pieces ${ }^{29}$, como as introduções escritas para os catálogos das exposições que organizou no Museu, New Spanish Painting and Sculpture [1960]; Franz Kline [1960]; Motherwell [1962]; Nakian [1964]; ou David Smith [1966]. No que concerne aos trabaIhos individuais, esses ensaios reluzem com aperçus brilhantes, contudo, são muitas as vezes em que encontramos frases como essas: "se podemos dizer que Make it newé o lema da arte estadunidense dos últimos tempos, Make it overé o da espanhola". ${ }^{30}$ Ou então: "nas camadas subterrâneas de toda grande obra do Expressionismo Abstrato e, de fato, florescendo dentro dela, encontramos a consciência traumática da urgência e a crise experimentada como acontecimento de ordem pessoal" [O'HARA, 1975a, p. 67]. Ou ainda: "seja na estilização arcaica das esculturas de Manship-uma espécie de idealização heroica fajuta do proletariado - ou na tardia estilização Art Nouveau de formas humanas e animalescas, a estilização segue como pauta principal [...]" [O'HARA, 1975a, p. 82]

Contudo, se voltarmos para algumas críticas de O'Hara - suas resenhas para a Art News e Kulchur, suas entrevistas e biografias - uma perspicácia crítica bem diferente vem à tona. As primeiras resenhas [1953-54] são peculiarmente literárias; nelas, o recém graduado em Harvard ainda faz um uso mais explícito do seu aprendizado. Assim, lança-se sobre as figuras na pintura de Kenneth Callahan: "suas anatomias podem ser à la El Greco, mas não é na pintura que encontram seu habitat, e sim na poesia romântica, onde as figuras ganham vida através das névoas peroladas de Shelley - o que às vezes na pintura é apenas cinza sobre tela". ${ }^{31}$ Em Kees Van Dongen, os seios das mulheres "aparecem e desaparecem como em algum dos momentos mais reveladores de Proust". ${ }^{2}$ As "densas imagens pintadas" de Helen Frankenthaler possuem "a sordidez condensada de um daqueles capítulos indiziveis ${ }^{33}$ de Henry James". ${ }^{34}$ Paralelamente, no entanto, quando escreve sobre a exposição de Adolph Gottlieb em abril de 1954 na Kootz Gallery, O'Hara tece um comentário sofisticado a respeito da "multiplicidade de matrizes e situações alocadas tanto entre elas quanto atrás delas" e pontua que "na superfície, as espessas pinceladas são menos um indício em direção a significados particulares do que a velocidade que se origina tanto na vitalidade como na alegria". 35

Com seu ingresso em 1955 como Assistente Especial do Programa Internacional no Museu de Arte Moderna de Nova York, O'Hara se manteve tão ocupado organizando as exposições itinerantes durante os anos seguintes que sua produção crítica 
foi mais escassa. No entanto, esses foram anos de intenso contato com o mundo da pintura e escultura contemporâneas e, no final dos anos 50, quando O'Hara estava no auge de seu domínio poético, ele também se dedicava de forma muito mais casual e espontânea aos escritos sobre arte, e ainda assim com maior seriedade. Somente entre 1958 e 1960 O'Hara publicou os seguintes títulos: o livro sobre Jackson Pollock para a série Great American Artist da editora Braziller; as entrevistas conceituadas com Franz Kline e Larry Rivers; um ensaio engenhoso e perspicaz sobre a tela Next to Last Confederate Soldier de Rivers; e diversos textos curtos sobre Pollock, Cavallon, Norman Bluhm ou que diziam respeito, como já mencionado, a temas como arte estadunidense vs. arte não estadunidense.

Em 1959, quando Jackson Pollock foi publicado, Hilton Kramer chamou o livro de um exemplo de "escola 'poética' da crítica", e vários críticos de arte foram contrários à prosa pretensiosa e à resposta intensamente pessoal do poeta ao pintor ${ }^{36}$. Mesmo assim, a publicação acabou se tornando um imenso sucesso e, apesar dos deslizes mencionados anteriormente, segue sendo até hoje uma célebre análise do trabalho de Pollock. As proposições sobre os conceitos gerais da Action Painting podem até não ser mais do que uma reafirmação do que já havia sido cunhado por Harold
Rosenberg: por exemplo, a concepção da "parede" em oposição ao "cavalete"; a pintura como campo de energia no qual o poeta adentra; a rejeição da metáfora e do símbolo em privilégio da própria materialidade - tinta como tinta, malha de arame como malha de arame. No entanto, os comentários paterianos de O'Hara são extremamente valiosos quando abordam certas pinturas em particular, porque fazem com que o leitor dedique a tela um segundo olhar, encarando-a novamente como se a visse pela primeira vez.

A pintura White Light de Pollock, por exemplo, "possui um glamour de tipo lendário, ardente, amargo e perigoso, algo semelhante às histórias de vulcões que seduzem os nativos até a borda da cratera, deixando que se atirem pelo fascínio de suas vibrações e pela magnitude de suas ondas de vapor" [O'HARA, 1975a, p. 29]. Já em Number 1, 1948, extrai sua potência de uma estratégia bem diferente: o langor inquietante de White Painté substituído por "um vigor extasiante, irritável e exigente. Em seu traço, uma velocidade fantástica aliada a uma legibilidade frenética; e as mãos aparentemente ensanguentadas do pintor, atravessando a parte superior da tela, logo depois da área principal do desenho, sugerem o epílogo de uma experiência terrível" [O'HARA, 1975a, p. 31]. É interessante acompanhar a variação do estilo 
formal, distante e de alguma forma até comportado no ensaio sobre Pollock - um estilo regido, pelo menos em parte, pelas convenções do que seria a escrita de um "Iivro de arte" - para o tom muito diferente empregado nos ensaios relacionados à obra de Larry Rivers. O trabalho de O'Hara como crítico parece ter sido mais fortuito quando teve a liberdade de escrever sobre um pintor que também era um grande amigo. Para além disso, os textos dedicados a Rivers compõem em forma de prosa uma partitura complementar aos seus poemas / do this, I do that, como A Step Away from Them ou Joe's Jacket".

Assim como todas as entrevistas de O'Hara, Larry Rivers: Why I Paint as I Do / Larry Rivers: porque pinto como pinto é notável devido ao apagamento da própria presença do poeta ${ }^{37}$. As perguntas de O'Hara são curtas e objetivas: ele possui, obviamente, o completo domínio do que vai falar, mas não se afoba em um exibicionismo do próprio conhecimento. Por outro lado, o Rivers que se desenha na entrevista acaba por soar como o próprio O'Hara, de forma que, por uma via mais tortuosa, o poeta revela-se afinal ali. Curiosamente, a doutrina expressa no manifesto Personismé então encarnada na entrevista: as palavras estão achatadas no espaço preciso entre duas pessoas, de forma que poeta e pintor se tornam um. Uma descrição imagética do ateliê de Rivers precede o diálogo:

Depois de descrever os agregados do lar da família Rivers, incluindo "Amy, uma adorável e frenética pastor-alemão", e mencionar as pinturas que habitavam as paredes do ateliê naquele momento, O'Hara complementa:

Outra parede comporta a gigantesca tela Journey of 1956, que parece até menor quando alocada no espaço do ateliê; próximo a ela, atrás do vaso de planta, a figura de Psiquê ou Afrodite em gesso comercial resgatada por Rivers de uma boate; pendurada na mão suspensa da estátua, uma lâmpada laranja que é também a luz noturna de Rivers [O'HARA, 1975a, p. 107]

A conversa que se segue vem permeada pelo tom versátil e cômico dessas observações. Mesmo que venham de contextos muito diferentes, Rivers e O'Hara acabaram compartilhando estéticas surpreendentemente similares. Rivers, nascido em uma família judia sem posses, cresceu "nas 
ruas do [...] Bronx" [O'HARA, 1975a, p. 109]. No começo, era músico de jazz, depois, tendo passado um período no posto de entregador numa loja de materiais artísticos, passa a trabalhar com Hans Hofmann e a frequentar a Universidade de Nova York [NYU] pela noite, iniciando seus estudos em pintura. Durante todo o tempo, Rivers contou com o suporte de Mrs. Bertha Burger, sua ex-sogra e uma de suas principais modelos, que cuidava da casa e de seus dois filhos para ele, ajudando-o a se sustentar ${ }^{38}$. É nítido que suas vivências eram bem distantes do meio católico provinciano de Baltimore e Grafton, Massachusetts, no qual Frank foi criado, ou da Harvard de John Ashbery e Kenneth Koch, ou mesmo do mundo sofisticado do Museu de Arte Moderna de Nova York.

No entanto, para qualquer pessoa que tenha lido O'Hara, a visão Eu posso ver uma coisa - digamos, uma fita que resolvo usar para dinamizar uma área de aproximadamente 7 centímetros da tela. Essa mesma fita pode acabar se transformando em um pote de leite, uma cobra ou um retângulo. [...] Pode até ser que eu chegue a desenvolver as minhas próprias associações sobre ela, mas não quero interpretar essa associação. [...] Não tenho o menor pudor em me apropriar da aparência dessas coisas - aquele pedaço de fita - sem definir qualquer significado específico a elas enquanto objetos. [O'HARA, 1975a, p. 118] nhas teorias”, diz ele, soando igualzinho a O'Hara, "sobre a arte dos últimos cem anos é que o tédio, a insatisfação e a perversidade do artista, mais do que qualquer outra coisa, foram as causadoras de grande parte das alterações na imagem da pintura" [O'HARA, 1975a, p. 113]. Com O'Hara, ele também divide a predileção por um certo tipo de humor exagerado, como o que se apresenta na pintura de George Washington. Para Sam Hunter, essa é capaz de agregar "historicidade e nostalgia à dimensão dos objetos e emblemas do senso comum" numa assimilação do "folclore popular ao alto estilo de arte sofisticada". ${ }^{39}$ de Rivers sobre arte é imediata-

mente reconhecivel. Ele rejeita a primazia do tema na pintura, insistindo que a forma [o como] suplanta o conteúdo [o quê]. Assim como O'Hara, ele enfatiza o valor do "acontecimento presente" [O'HARA, 1975a, p. 108], da energia, do papel do "acidente" na arte [O'HARA, 1975a, p. 117], e a necessidade de expurgar "os desconfortos do tédio". "Uma das mi-
"Um self-service sem balança ${ }^{40}$ daquilo que é reconhecivel" - para Rivers, essa seria a melhor definição da pintura.

E quando Frank Ihe pede para aplicar esses princípios na tela recém pintada 2nd Avenue with THE, Rivers explica: 
O que você vê é a vista de um ateliê na Second Avenue - um ateliê no último andar - olhando em direção aos prédios do outro lado. Na tela apresento uma pequena seleção de objetos escolhidos dentre todos os outros que podiam ser vistos a partir da minha perspectiva. Os retângulos são os reflexos emitidos pelas janelas de vidro do outro lado da rua. As linhas verticais escuras são as tábuas do assoalho do estúdio. Eu olhei para baixo, notei que estavam ali e as pintei. As linhas horizontais são os parapeitos das janelas. À direita, os semicírculos são os pratos de uma bateria. Os quadrados brancos pequenos em linha são as teclas brancas de um piano que eu tinha lá no ateliê. E quanto à figura da mulher-foguete, ela também estava dentro do estúdio e entrou no meu campo de visão. Lá em cima, as letras THE num formato diminuto - logo à esquerda delas tem uma mulher se inclinando para fora da janela do prédio em frente. Eu deveria ter incluído o letreiro ALPINE lá em cima também. Foi assim que algum construtor resolveu chamar um daqueles prédios -chique esse nome, não é? [O'HARA, 1975a, p. 118]

"E qual a história dessas letras THE?" -Frank pergunta. Rivers responde: "essas letras foram cola- das na janela do ateliê por algum diretor de cinema que quis fotografá-las para o fim de seu filme. A outra parte END acabou desaparecendo" [O'HARA, 1975a, p. 118]

Cito essa passagem extensamente porque ela evidencia as estreitas conexões entre a pintura de Rivers e o poema Second Avenue de O'Hara, escrito alguns anos antes no ateliê do pintor ${ }^{41}$. Assim como Rivers se apropria de objetos familiares [as tábuas do assoalho, o parapeito da janela, a mulher e o letreiro colado na janela do espaço] e os desloca - criando uma nova tensão entre detalhes ilusionistas e configurações abstratas O'Hara extrai suas imagens das cenas de rua da

Com candura. $\bigcirc$ passado, as sensações do passado. Agora! a escrita cuneiforme dos guarda-sóis de sátrapas carroças de cachorro quente e maionese caseira, da areia ornando o prepúcio nas sungas, das lojas de revelação Fujifilm, da Mesbla, do Kenneth em uma gôndola abandonada no domingo cortando ainda mais sugerindo lobotomias de um ainda-por-vir-mais-dócil mundo de ouvidos, do sambista recobrando a voz na roda de partido alto, Bill, de "Faz amor comigo até o dia clarear!" "Lá lá ia lá ia lá ia lá ia!...", de uma mão frouxa maior que o joelho, que parece dizer "Addio" e é capaz de renunciar ao desastre que ela mesma provocou em terra.

Acres de vidro não deixam mais claro o sinal da paisagem menos enluarada que na pré-história, ainda assim menos distante, ávida, morta! ${ }^{42}$ [O'HARA, 1971, p. 146] 
Second Avenue, cortando, distorcendo e realocando os elementos de modo que sua versão final não absorva mais do que "rastros" daquilo que está sendo representado:

A ambiguidade no referencial criada pelo isolamento da expressão "com candura"; o deslocamento de "o passado" para "agora"; as imagens de fachadas comerciais e carrinhos de mão "dissolvendo" em pensamentos sobre Kenneth Koch; as memórias de um show; as alusões ridículas ao poema The Waste Land na linha 8; a controversa imagem final de uma paisagem azulada ${ }^{43}$ "ainda assim menos distante, ávida, morta!" - assim como Rivers descreve a entrada de fragmentos similares na sua pintura, é a partir da invasão aleatória do fluxo de consciência do artista que todos esses elementos encontram um lugar no poema.

Desse modo, O'Hara é o intérprete ideal para o trabalho de Rivers, que assim como Graça Hartigan, foi um pintor que rejeitou, de um lado, a pura abstração e, de outro, a pintura figurativa "direta" - o que Rivers costumava chamar de "realismo afetado" [O'HARA, 1975a, p. 119]. Ambos os artistas expandem o potencial significativo dos objetos comuns; as teclas brancas do piano e o parapeito da janela em Second Avenue with THE de Larry Rivers correspondem a imagens como a "antiga moeda romana", a "cabeça de parafuso", ou "os construtores civis com seus capacetes prateados" no Poema Pessoal de O'Hara [O'HARA, 1971, p. 235].

No livro de memórias de 1965, intitulado Larry Rivers, O'Hara relembra os pontos de contato entre o poeta e o pintor. A chegada de Rivers à cena da pintura nova-iorquina é ironicamente comparada ao aparecimento de "um telefone demente. As pessoas não sabiam se o deixavam na biblioteca, na cozinha ou no banheiro. Mas ele estava sempre ligado" [O'HARA, 1971, p. 512]. Como o próprio O'Hara, Rivers era "inquieto, impulsivo e compulsivo", não conseguindo tolerar a existência de uma estética que separasse as artes visuais do jazz e da poesia, suas duas outras paixões. "Seu trabalho", diz O'Hara, "é muito mais como um diário de suas vivências. Enquanto boa parte da arte de nosso tempo se envolveu em reflexões explicitamente conceituais ou éticas, Rivers, de forma desautomatizada, escolheu trabalhar sobre aquilo que o preocupava e o entusiasmava" [O'HARA, 1971, p. 514]. Creio que O'Hara quis dizer com isso que em determinado momento da nossa história, quando o Expressionismo Abstrato corria o risco de caminhar em direção à mera padronização e repetição, Rivers, que assim como De Kooning nunca abriu mão da presença de alguns elementos figurativos - contornos de seus 
próprios dedos, letras escritas, a silhueta do rosto de uma mulher, além de outros gestos ilusionistas -, mudou o rumo da pintura em Nova York. É nesse sentido que sua arte está especialmente próxima do estilo lírico de O'Hara. Não à toa, uma parceria entre duas sensibilidades tão afins só poderia gerar bons frutos.

\section{POEMAPINTURAS}

A colaboração entre poetas e pintores é em grande parte um fenômeno do século XX. Mas a colaboração genuína - ao contrário da ilustração que é, por definição, ex post facto - é algo raro em todos os tempos, dada a dificuldade para encontrar o equilíbrio entre dois gêneros aparentemente tão antagônicos. Seja ele realizado por um único artista ou como fruto de colaboração, um poemapintura tende a se tornar uma pintura com um punhado de palavras distribuídas como parte do esquema visual, ou inversamente, um poema ilustrado no qual imagens visuais encontram-se subordinadas ao sentido verbal. Todavia, sob as circunstâncias adequadas, o poemapintura, fruto da colaboração entre artistas, apresenta grande potencial. Como a ópera, o ballet, a mascarada e o cinema de animação, poemapinturas são capazes de proporcionar o prazer particular gerado pela interação de meios e técnicas sem relação aparente.

Assim como no caso de sua crítica de arte, o conceito de poemapintura em O'Hara remonta a Apollinaire, que escreveu poemas "seguindo" pinturas ${ }^{44}$ [colando o poema Les Fenêtres no verso da pintura homônima de Delaunay, a fim de criar uma espécie de imagem dupla], e cujos Caligramas contêm experimentos fascinantes de composição verbo-visual. Em // Plêut, por exemplo, as palavras escorrem pela página da esquerda para a direita como gotas de chuva; em La Cravate et la Montre, a disposição das palavras imita os dois objetos nomeados pelo título; e em Visée [Alvo], as variações de posição das linhas correspondem às atitudes cambiantes do poeta ${ }^{45}$.

Mas nenhum destes exemplos constitui, em um sentido estrito, poemapinturas. Um modelo mais próximo das colaborações de O'Hara pode ser encontrado no Dadaísmo e no Surrealismo, ainda que a peinture-poésie de Picabia, Schwitters, Magritte ou Ernst quase nunca tenha resultado de colaborações. Uma pintura como a famosa M'Amenez-Y [1919-1920] de Picabia é um bom exemplo da experimentação conduzida pelos dadaístas em torno dos padrões verbais e visuais ${ }^{46}$. Suas formas mecânicas banais [dois semicírculos, um cilindro e um parafuso] são justapostas ao título que se baseia em um dos ready-mades verbais de Marcel Duchamp: M'Amenez-Y ["me traga lá"] é uma substituição para a formulação 
correta Amenez-y-moi, e também uma brincadeira com a palavra amnésie[amnésia]. Na parte superior da tela, Picabia anuncia em tom cômico se tratar de um retrato pintado em óleo de rícino [l'huile de ricin] e dentro dos círculos encontramos as palavras peinture crocodile [pintura crocodilo] e ratelier [dentadura] d'artiste - num divertido jogo de palavras. No canto inferior direito, a assinatura do artista é destacada; do lado esquerdo, a referência sem sentido a Pont- L'Evêque [uma pequena cidade produtora de queijos na Normandia] como o lugar em que M'Amenez-Y teria sido executada. Sem dúvida, as palavras de Picabia não são um poema, mas a sua composição depende de uma conjunção particular de imagens verbais e visuais.

Nesse mesmo período, as colagens de Kurt Schwitters constituem um tipo diferente de poemapintura. Em seu ensaio Merz[1920], Schwitters declara: "O meu desejo não era o de ser um especialista em um único ramo da arte, mas sim o de ser um artista. 0 meu objetivo é a Merz [uma peça sobre a merda] enquanto composição artística. Primeiro eu combinei categorias individuais de arte. Eu juntei palavras e frases em poemas de maneira a produzir um design rítmico. Revertendo o processo, colei imagens e desenhos de forma que neles fosse possivel ler frases". ${ }^{47}$ Exemplos desses dois processos podem ser encontrados em Collage[1920] e Sonata [1923], ambas reproduzidas no livro The Dada Painters and Poets, de Motherwell, que O'Hara conhecia e ama$v^{48}$. Sonata é sobretudo verbal: palavras curtas e sem sentido encontram-se dispostas em colunas segundo variadas configurações fonéticas, e a pequena colagem retangular no canto inferior direito desempenha um papel subordinado. O trabalho é um exemplo precoce da poesia concreta. Em Collage, por outro lado, recortes de jornais e posters são reunidos de forma que pedaços de manchetes, palavras, frases e partes de frases apresentam-se dispersas pela superfície, de baixo para cima e de cima para baixo. Essas duas colagens são experimentos interessantes, mas a relação entre palavra e imagem visual parece ser fundamentalmente arbitrária.

\section{A peinture-poésie de René Magritte acena para a} Pop Art. Uma pintura como A Traição das Imagens [1928-1929] contém o que parece ser uma réplica realística de um grande cachimbo contra um fundo em branco. Abaixo da tela aparece a legenda Ceci n'est pas une pipe ${ }^{49}$. Mas, como argumenta William Rubin, a pintura não é tão simples como parece à primeira vista, pois "a mera reprodução de qualquer objeto tridimensional em uma superfície plana delimitada - ou seja, sua transposição em imagem - engendra automaticamente uma série de associações estéticas que não guardam relação direta com o significado daquele objeto enquanto objeto" 
[RUBIN, 1967, p. 94]. Em outras palavras, a imagem do cachimbo não equivale a um cachimbo real. A legenda didática Ceci n'est pas une pipe complexifica o esquema, pois a palavra pipe libera diferentes sinais em relação à imagem do cachimbo e ao cachimbo real. Embora limitada, uma ressonância se estabelece, portanto, entre imagens verbal e visual.

Contudo, os poemapinturas mais interessantes do Surrealismo são os de Max Ernst, nos quais palavra e imagem não se encontram meramente justapostos como nas colagens de Magritte ou Picabia, mas fundidos de maneira a formar o que Lucy Lippard descreveu como uma "afirmação genuinamente intermediária ${ }^{50 " . ~ E m ~ u m ~ e n s a i o ~ d e n o m i n a d o ~ P a r a ~}$ além da pintura, escrito em meados dos anos 1930 , Ernst define a colagem como uma "composição alquímica de dois ou mais elementos heterogêneos cujos resultados de sua inesperada reconciliação caminham [...] em direção à confusão sistemática e à 'desordem dos sentidos' [Rimbaud], ao acaso ou ao desejo do acaso ${ }^{51 " . ~ A ~ " p a l a v r a ~ c o l a g e m " ~}$ favorita de Ernst [a palavra-chave que o artista utilizava como guia para o processo de execução da colagem] é phallustrada, que ele definiu como "um produto alquímico composto dos seguintes elementos: uma autoestrada, uma balaustrada, e um certo número de falos". Assim, a colagem Dada o chapéu faz o homem [Fig. 2] é, nas palavras de
Lippard, uma "phallustrada em todos os sentidos, o jogo visual prolongado através dos jogos verbais na inscrição que acompanha a imagem: "Bedecktsamiger stapelmensch nacktsamiger wasserformer ['edelformer'] kleidsame nervatur auch UMPRESS NERVEN! [C'est le chapeau qui fait l'homme, le style c'est le tailleur]"52.

É praticamente impossível traduzir o trecho para o português, uma vez que cada palavra é um trocaditho ou apresenta um duplo sentido: Bedecktsamiger significa "coberto" mais "semeado" ["coberto de sementes?"]; edelformercombina o sentido de edel [elevado, nobre, precioso, aristocrático] com conotações eróticas pois "edle Teile" são partes íntimas, e portanto "edelformer" pode dar a entender tanto "aquele/a que tem elegantes genitais" como a pessoa que observa as formas ou que cria elegância. A colagem em si é uma página de um catálogo de chapéus, transformada através de aquarela, lápis, tesoura e cola em uma série de vinhetas esculpidas com características mecânicas, orgânicas, cartunescas e até mesmo narrativas. Nessa engenhosa e intrincada phallustrada, "palavras e formas saltam e ricocheteiam umas sobre as outras em uma ação transdisciplinar e referências cruzadas, que continua a oferecer surpresas muito tempo depois da decodificação inicial" [LIPPARD, 1970, p. 13].

Ernst levou essa espécie de "arte literária" [obser- 
va-se que não se trata de uma ilustração no sentido convencional] ainda mais longe em La Femme 100 têtes [A Mulher Cem Cabeças], uma "novela-colagem" na qual o artista coleta uma série de xilogravuras encontradas em revistas e as corta de forma a descobrir uma nova "realidade" figurativa através do encontro ao acaso de imagens previamente não relacionadas. A cada imagem resultante do processo foi atribuída uma legenda poética. Tomadas isoladamente, nem a imagem nem a legenda são capazes de

transmitir o "enredo": na verdade, nas palavras de Lucy Lippard, elas oferecem "um duplo ponto de vista que forma uma unidade estereofônica. o leitor deve literalmente ler entre as linhas da interação verbo-visual, projetando-se a si mesmo no es- paço intermediário entre imagem e legenda". Aliás, a novela-colagem possui uma estrutura análoga ao filme: "o deslocamento pictórico da ação e da sequência justapostas contra as legendas ambíguas, aparentemente fora de sintonia, sugere um filme silencioso com legendas numa língua estrangeira. De forma impressionante, a mixagem é feita na mente do leitor" [LIPPARD, 1970, p. 13].

O uso que Ernst faz da novela-colagem e da phallustrada, portanto, olha para o futuro, num

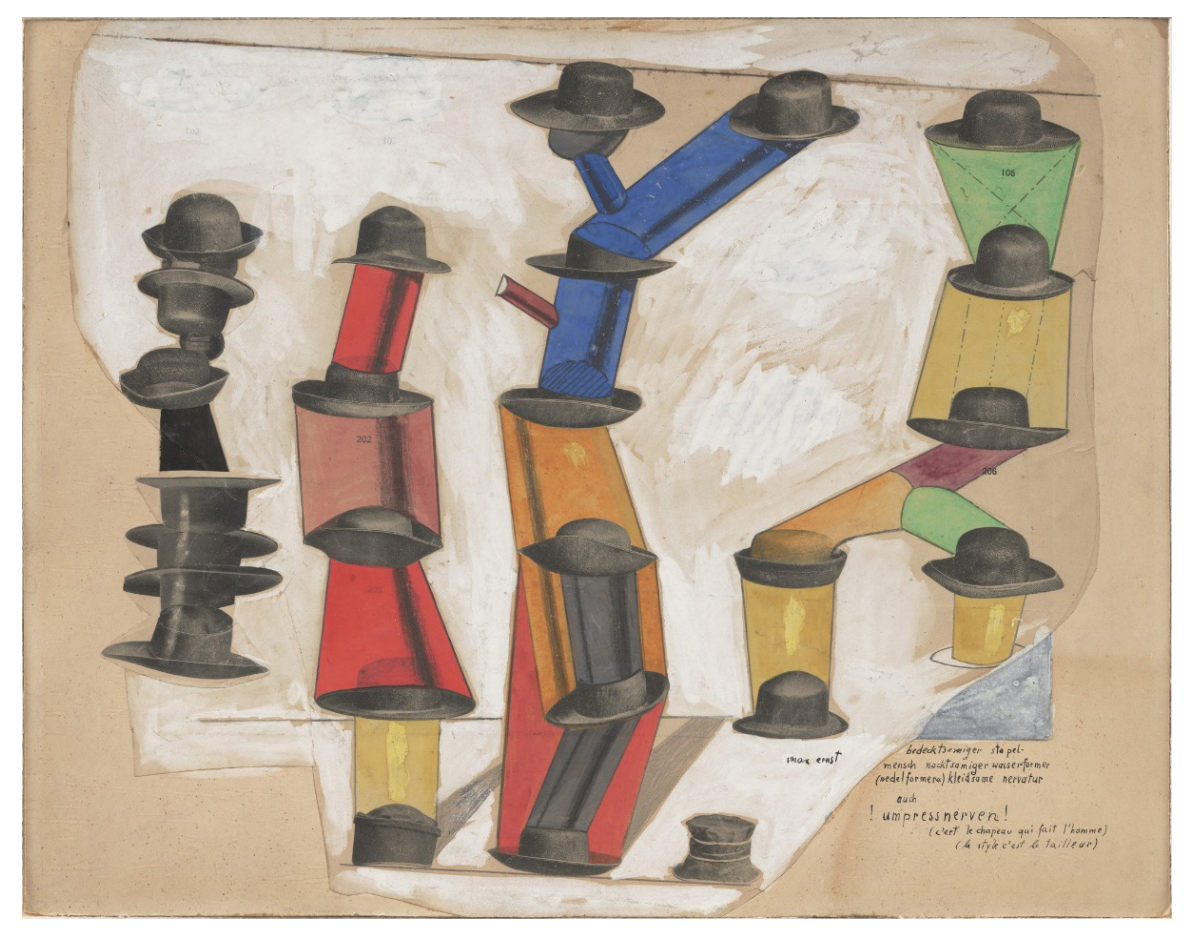

Fig. 2. Max Ernst. O Chapéu faz o homem. 1920. Colagem com lápis, tinta e aquarela, $14 \times 18$ polegadas. Museu de Arte Moderna, Nova York. aceno aos

poemapintu-

ras de nosso tempo. Mas é importante lembrarque Ernst era, em primeiro lugar, um artista visual, de maneira que até mesmo suas colaborações com Paul Éluard em Repetitions [1921] e Les Malheurs des Immortels [1922] não são 
colaborações verdadeiras, conquanto nesses

livros, Ernst toma um poema de Éluard já previamente escrito para ilustrá-lo. Faltava dar o próximo passo: que um poeta e um pintor trabalhassem simultaneamente na mesma área espacial, jogando com palavras e imagens visuais a fim de produzir novas formas. É o que acontece em Stones / Pedras, a série de litografias feitas por O'Hara e Rivers entre os anos de 1957 e 1960.

Em um ensaio muito divertido chamado Vida entre as pedras ${ }^{53}$ [1963], Rivers descreve a origem em termos técnicos quanto em termos estéticos", observa Calvin Tompkins em seu estudo das técnicas contemporâneas de impressão, "as publicações da Universal Limited Art Editions de Tatyana Grossman [que contam em seu acervo com mais de cem litografias de Jasper Johns, além da intrigante série de litografias em plexiglas Shades, de Robert Rauschenberg] são geralmente reconhecidas por serem iguais ou superiores a qualquer publicação que tenha sido feita na Europa ou em qualquer outro lugar"54 [TOMPKINS, 1976, p. 58]. dessas litografias. O pintor relembra que "tudo começou com essa moça siberiana chamada Tanya, que veio à minha casa no verão de 1957. Naquele momento, sua vida Ihe exigia que se ocupasse de uma atividade. Ela encontrou essa atividade e passou a se dedicar com uma fúria delicada à produção de litografias... Ela queria que eu trabalhasse em pedras litográficas com um poeta. Ela tinha a devoção, o meio e o desejo de imprimir" [RIVERS, 1963, p. 91]. "Tanya, a moça siberiana", como Rivers a chama comicamente, era na verdade Tatyana Grossman, cuja oficina gráfica em West Islip, Long Island, é hoje em dia internacionalmente conhecida. "Tanto
Eu fui ver [...] Barney Rosset na Groove Press para perguntar se ele poderia sugerir um poeta para a realização de um livro como esse [das pedras litográficas] e ele sugeriu Frank O'Hara. Bom, eu havia lido alguns dos poemas de O'Hara, mas eu não os entendi muito bem, eram muito abstratos. Alguns dias depois [...] eu fui até o ateliê de Larry Rivers em Southampton para conversar com Larry sobre essa ideia de um livro que fosse uma fusão real entre poesia e artes visuais, uma colaboração verdadeira, não apenas desenhos para ilustrar poemas. Depois de ouvir, Larry gritou "Hey, Frank!" e descendo as escadas apareceu um jovem homem em jeans azuis. Era Frank O'Hara. [GROSSMAN apud TOMPKINS, 1976, p. 61]

Tatyana Grossman recorda que a escolha de Frank O'Hara como colaborador de Rivers foi o resultado de uma série de coincidências oportunas:

Rivers estava maravilhado que aquela "moça siberiana não encontrara apenas um pintor e um poeta que topassem trabalhar juntos, mas dois homens que realmente conheciam os trabalhos um do outro e suas trajetórias de vida" [RIVERS, 1963, p. 92]. Apesar de seus "egos terrivelmente inflados e super-sérios", 
Rivers e O'Hara viram o que tinha de ser feito: "Frank O'Hara não ia escrever um poema ao qual eu acrescentaria uma imagenzinha bacana depois. Tampouco tínhamos a expectativa de que o mundo estivesse aguardando pela sua poesia e pelo meu desenho, como as "colaborações" do passado agora parecem ter feito" [RIVERS, 1963, p. 93].

Trabalhar na pedra litográfica revelou-se um novo desafio para O'Hara e Rivers, que se viam como herdeiros da tradição de "Picasso, Matisse, Miró, Apollinaire, Eluard e Aragon" [RIVERS, 1963, p. 92]. Rivers descreve as dificuldades impostas pela mídia em questão:

A superfície da pedra litográfica é muito suave. As marcas que vão nela podem ser feitas com um lápis pastel difícil de manusear, ou com um líquido preto chamado Touche. [...] Tudo aquilo que você faz é impresso de forma espelhada, oposta à maneira que você desenhou na pedra. Para que a escrita pudesse ser lida, ela precisava ser feita de trás pra frente. É quase impossivel rasurar, uma das minhas muletas mais importantes. Tecnicamente era uma tarefa realmente trabalhosa, que demandava a paciência de uma outra época. Mas a nossa ignorância e entusiasmo nos permitiu mergulhar nisso sem pensar sobre os detalhes e as dificuldades. [RIVERS, 1963, p. 93]

A primeira das doze Stones foi chamada US [Fig. 3]. A descrição detalhada de Rivers sobre a criação desse trabalho nos ajudará a entender melhor o processo de colaboração:

Cada vez que nos juntávamos decidíamos escolher um assunto bem definido e como não havia nada a que tivéssemos mais acesso do que a nós mesmos, a primei- ra pedra seria chamada "us". Ah sim! O título sempre aparecia primeiro. Era o único jeito que tínhamos para começar, 'u' e 's' foram escritos no centro superior da pedra de trás para frente. Eu não sei se foi Frank quem escreveu as letras, mas lembro de decorá-las para que parecessem algum tipo de bandeira, aproximando-as das letras do nosso país ${ }^{5}$. Depois coloquei alguma coisa a ver com a testa de amolar faca e o nariz torto do Frank e parei. Com a ajuda de um espelho de mão redondo fiz alguns rabiscos para representar a minha cara. A combinação do 'u' e do 's' decorados com os nossos rostos [ver o canto esquerdo superior da imagem] fizeram Frank escrever "... eles nos chamam os peidões ${ }^{56}$ do nosso país...". Onde eu podia, fazia alguma coisa que tivesse relação com o título da pedra e ele ou comentava sobre o que eu havia feito ou levava isso para um outro lugar. Por vezes eu indicava uma área que eu tinha certeza que iria deixar vazia para que ele escrevesse ali. Em outros casos, colocava alguma coisa na pedra e pedia que ele escrevesse o que quer que desejasse, pedindo no entanto que começasse numa parte específica da pedra e terminasse formando um quadrado ou retângulo de palavras, de maior ou menor tamanho, sobre ou em volta das minhas imagens. [RIVERS, 1963, p. 93]

Rivers enfatiza o caráter improvisado da colaboração, sua qualidade de evento ou happening, em detrimento de uma "obra de arte" pré-determinada 


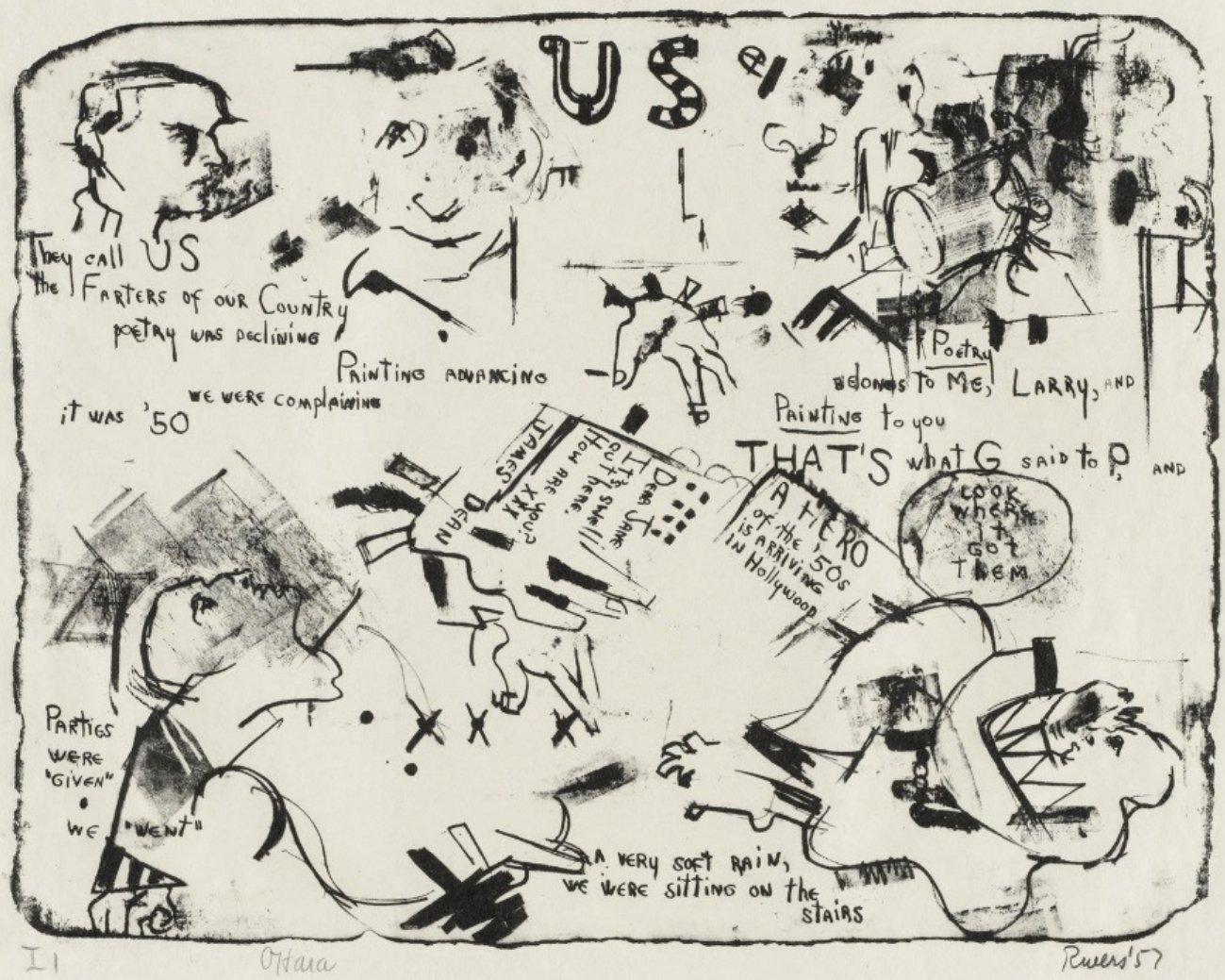

Fig 3. Larry Rivers e Frank O'Hara. US, Primeira pedra de Stones, 957-60.

Litografia, $19 \times 23$ 1⁄/4 polegadas. Museu de Arte Moderna, Nova York. Doação do Sr. e da Sra. E. Powis Jones. 
ou planejada. Mas isso não quer dizer que vale tudo: o relato deixa claro que a cada etapa do trabalho, os dois artistas dependiam da reação um do outro. É por isso que constitui um equívoco denominar Stones, como faz um crítico do trabalho, "não mais que frufru para sustentar as brincadeiras de uma festa avant-garde de duas pessoas, endereçada somente àqueles que pudessem reconhecer nomes, alusões e eventos, bem como o espírito de exclusividade que eles exaltam ${ }^{57 "}$ " [TILLIN, 1959, p. 62]. Pois, embora US não seja uma das melhores litografias da série - a superfície é um tanto desordenada e O'Hara ainda não dominara a técnica do lettering, tornando penosa a tarefa de escrever de trás para frente a menos que se tenha em mãos um espelho -, ela tem uma estrutura nítida.

O motivo visual predominante é o rosto de Frank de perfil, com seu nariz torto e sua testa volumosa. Ele aparece no canto superior esquerdo, próximo ao esboço de Rivers visto frontalmente; então novamente ao contrário [em uma imagem espelhada ampliada] no canto superior direito, dessa vez sombreada e sobreposta a outras formas; novamente no canto inferior esquerdo, onde a cabeça é virada para baixo, unida a um torso contorcido cuja pose remete às figuras da Guernica de Picasso; e finalmente, no canto inferior direito encontramos, incorporada a uma forma de cartão de namorados, a face do poeta colada à face de Rivers, novamente vistas de frente e coladas bochecha com bochecha. Os rostos são colocados contra um fundo de garatujas, algumas delas lembram mãos, pernas, falos e formas animais; outras parecem remeter a ideogramas chineses.

As imagens verbais de O'Hara estão intimamente relacionadas a essa paisagem de posturas e gestos. A brincadeira com a palavra US não é apenas uma piada local - "Eles nos chamam os peidões do nosso país" -, mas o tema de todo o poemapintura, que retrata o heroísmo e anti-heroísmo de muitas formas. Assim, bem no centro da composição, O'Hara coloca uma carta de James Dean [o herói de Hollywood como uma vítima] a Jane [a pintora Jane Freilicher], estupidamente vazia: "Tudo ótimo por aqui. Como você está?". A carta é vista de cabeça para baixo, quase como se tropeçasse na placa: "Um herói dos anos 50 está chegando em Hollywood". Os próprios artistas se veem comicamente em descompasso com o seu tempo.

A poesia estava em declínio

A pintura avançava

A gente resmungava

Eram os anos 50 
Os historiadores da literatura estadunidense são unânimes em apontar que os anos imediatamente após a Segunda Guerra Mundial foram um período fraco para a poesia. O tom do período é transmitido pelas referências que O'Hara faz à discussão mesquinha - "A Poesia pertence a Mim, Larry, e a Pintura a você" - e à insinuação fofoqueira - "foi isso que G disse a P e...", evidentemente Gertrude Stein e Picasso ${ }^{58}$, numa linha levando ao balão, "veja aonde isso levou eles". Os jovens artistas são presunçosos: "Davam-se festas/a gente ia" é ironicamente colocado logo abaixo do que denominamos 'torso de Guernica'. No centro inferior da figura, O'Hara insere as frases:

Um chuvisco suave

Nos sentávamos nas escadas

A absoluta simplicidade dessas palavras em que poeta e pintor se tornam dois seres humanos ordinários compartilhando um momento de afeto cria um contraste eficaz com toda a bravata das primeiras linhas. O mesmo ocorre com a "cena dos namorados" que se encontra justo ao lado desses versos, no canto inferior direito, e cujo desenho se contrapõe aos dois retratos de aspecto formal e contornos agudamente definidos no canto superior esquerdo.

Dessa forma, a composição de US revela-se ao mesmo tempo complexa e engenhosa, palavras e imagens se fundindo de forma a criar tensões espaciais interessantes. Um poemapintura ainda mais vigoroso encontra-se na Stone de número 3, intitulada Rimbaud \& Verlaine [Fig. 4]. Nessa peça, a grafia das letras está muito mais precisa que em US, O'Hara já havia dominado com maestria a arte da "escrita-espelhada". O relato de Rivers sobre a composição dessa litografia é particularmente valioso:

Havia uma foto de Rimbaud e seu parceiro depressivo Verlaine no ateliê. Eu comecei a desenhar olhando para aquela imagem, quando recordamos uma noite no ballet do City Center. Durante um intervalo do espetáculo, descemos a longa escadaria dos assentos baratos ao mezanino, quando nosso amigo em comum e meu galerista John Myers, querendo ser engraçado, gritou para todo mundo ouvir "ali estão eles todos cobertos com sangue e sêmen". Essa é uma alusão a algo dito sobre Rimbaud e Verlaine com o que a esposa de Verlaine o perseguiu pelo resto de sua vida. Depois de se lembrar disso, Frank decidiu usá-lo, e em uma delicada série de duas linhas ele começou a escrever... Suas primeiras duas linhas tinham a ver com a poesia de Rimbaud e Verlaine. Ele trouxe as linhas para cima do meu desenho e parou... Então ele seguiu com alguma coisa sobre a escadaria e o balé. Eu esperei até ele terminar e no espaço restante [eu dirigi o espaço entre as linhas e a distribuição geral da composição] tentei desenhar uma escadaria... não serviu. Aqui eu descobri - quão difícil era apagar qualquer coisa - para apagar, é preciso raspar a área com uma lâmina. Por fim, comecei a fazer balas que também eram pênis com pernas. Uma simples resposta do Simon ao que Frank havia dito sobre a companhia de balé. Se existe alguma "arte" nessa litografia, sua presença continua um mistério. [RIVERS, 1963, p. 94] 


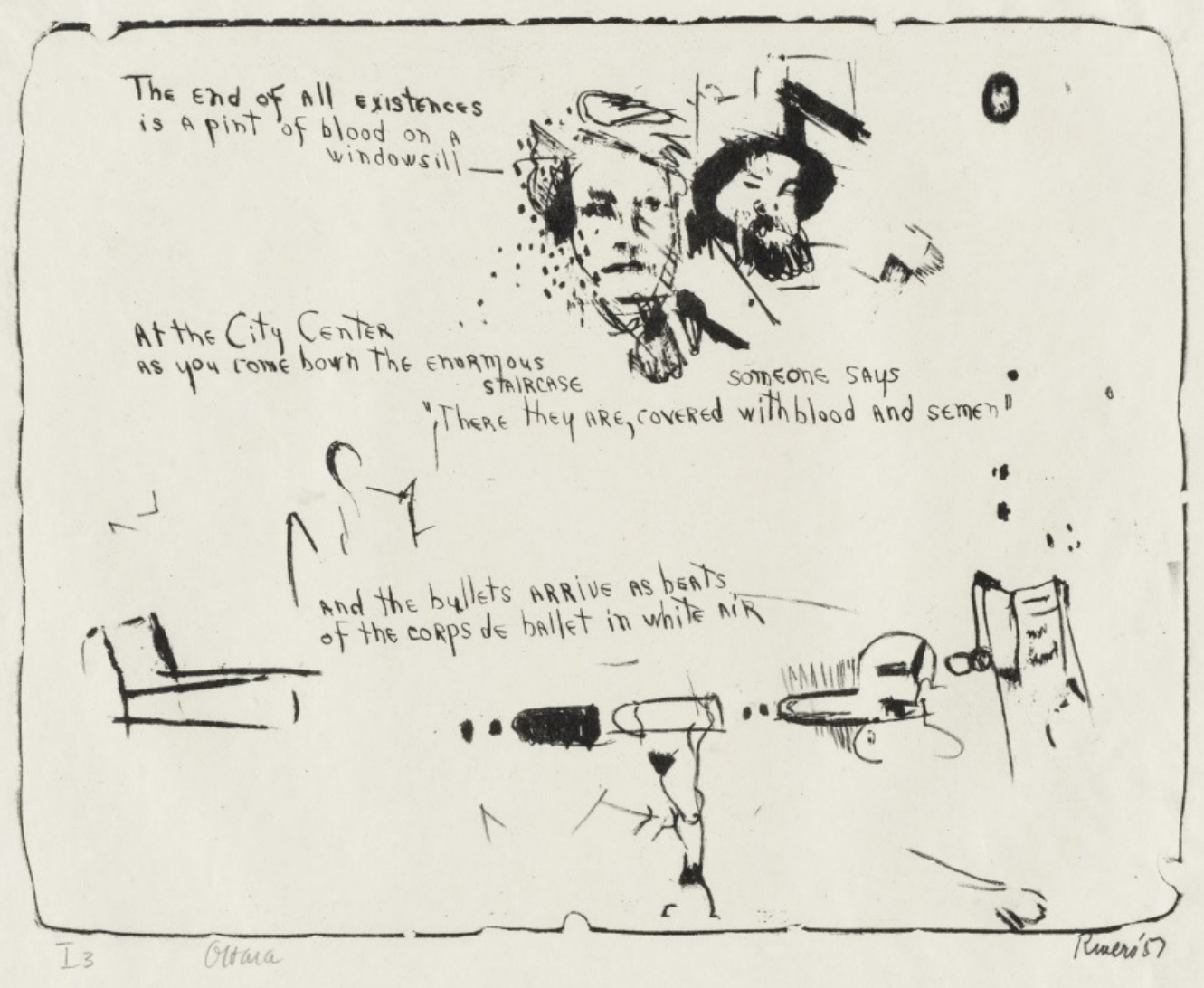

Fig. 4. Larry Rivers e Frank O'Hara. Rimbaud \& Verlaine. Pedra 3 de Stones, 1957-60. Litografia,

$19 \times 23$ 1/4 polegadas. Museu de Arte Moderna, Nova York. Doação do Sr. E da Sra. E. Powis Jones 
É claro que existe muita "arte" ali. O rascunho de Rimbaud e verlaine, um contraste de luzes e sombras, é brilhantemente representado: um belo Rimbaud de cabelos claros e olhos visionários é contrastado à figura um tanto mesquinha, pequena e oriental de Verlaine. Rimbaud claramente domina a cena, como ele fez na vida real. As linhas de O'Hara, “O fim de todas as existências/ é uma caneca de sangue no / parapeito da janela" são uma alusão à terrível novela de Bruxelas, quando Verlaine atirou em Rimbaud, oferecendo um comentário irônico para o retrato estático e discreto dos dois poetas. O motivo de sangue retorna então na referência à frase maliciosa de Myers feita no ballet, um comentário que relaciona O'Hara e Rivers a Rimbaud e Verlaine. A imagem de balas [pênis com pernas] é especialmente eficaz: essas formas se relacionam não apenas com as frases "batidas / da companhia de balé", e os movimentos do poeta e do pintor descendo a escadaria do City Center, mas igualmente com a relação de Rimbaud e Verlaine, que culminou no episódio dos tiros. Outros detalhes visuais aparecem: observe a forma semelhante a uma cadeira no canto esquerdo da composição, sugerindo o assento de uma galeria, e a silhueta de uma pessoa sentada logo ao lado, na plateia. As manchas pretas espalhadas pela superfície, por outro lado, lembram manchas de sangue. Uma quantidade relativamente pequena do espaço disponível na litografia é utilizada, de forma que predominam os espaços em branco, reforçando a referência de O'Hara ao "ar branco" na última linha. Rimbaud e Verlaine em um poemapintura no sentido pleno da palavra.

Amor [Fig. 5], uma das melhores litografias da série, relaciona palavra e figura de forma diferente. "Decidimos", lembra Rivers, "fazer uma pedra sobre o amor. Eu distribuí homens e mulheres sobre a superfície com algumas genitálias pelo sexo da coisa. Ele escreveu entre e sobre os desenhos e nunca sequer mencionou as palavras homem, mulher, corpos ou sexo" [RIVERS, 1963, p. 97]. A descrição é bastante precisa. Nos espaços entre as silhuetas de Rivers de corpos atléticos e masculinos e formas fálicas, O'Hara coloca as palavras de um poema cujo tom rebaixa totalmente a impressão visual:

Amor

Perder-se

estrelas trepam uma cadeira rota rubra nas sombras um tesão fraco e agita uma planta enrugada pela

chuva 


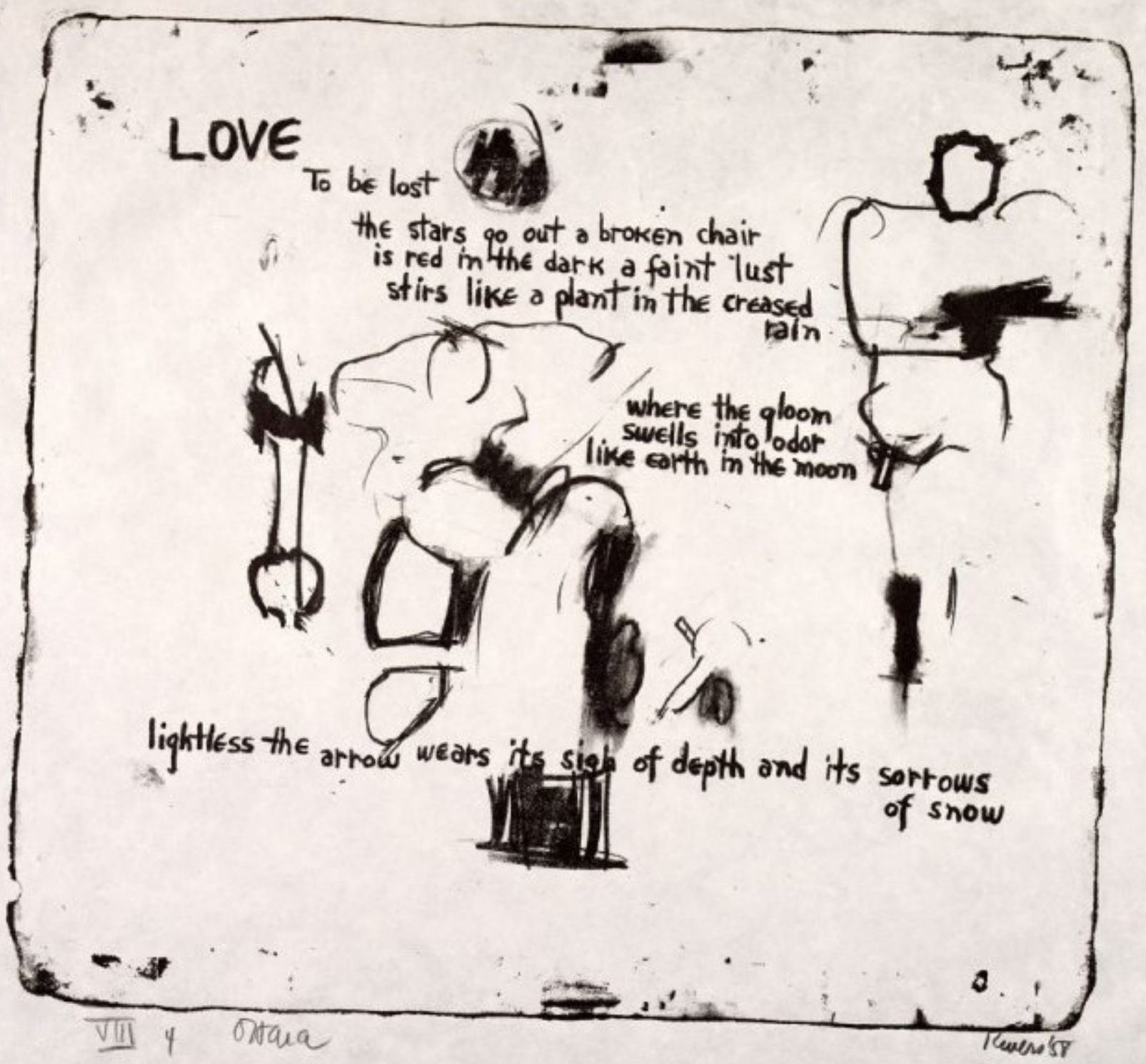

Fig. 5. Larry Rivers e Frank O'Hara. Love / Amor. Pedra 4 de Stones, 1957-60. Litografia, $19 \times 23$ 1/1/4 polegadas. Museu de Arte Moderna, Nova York. Doação do Sr. E da Sra. E. Powis Jones. 


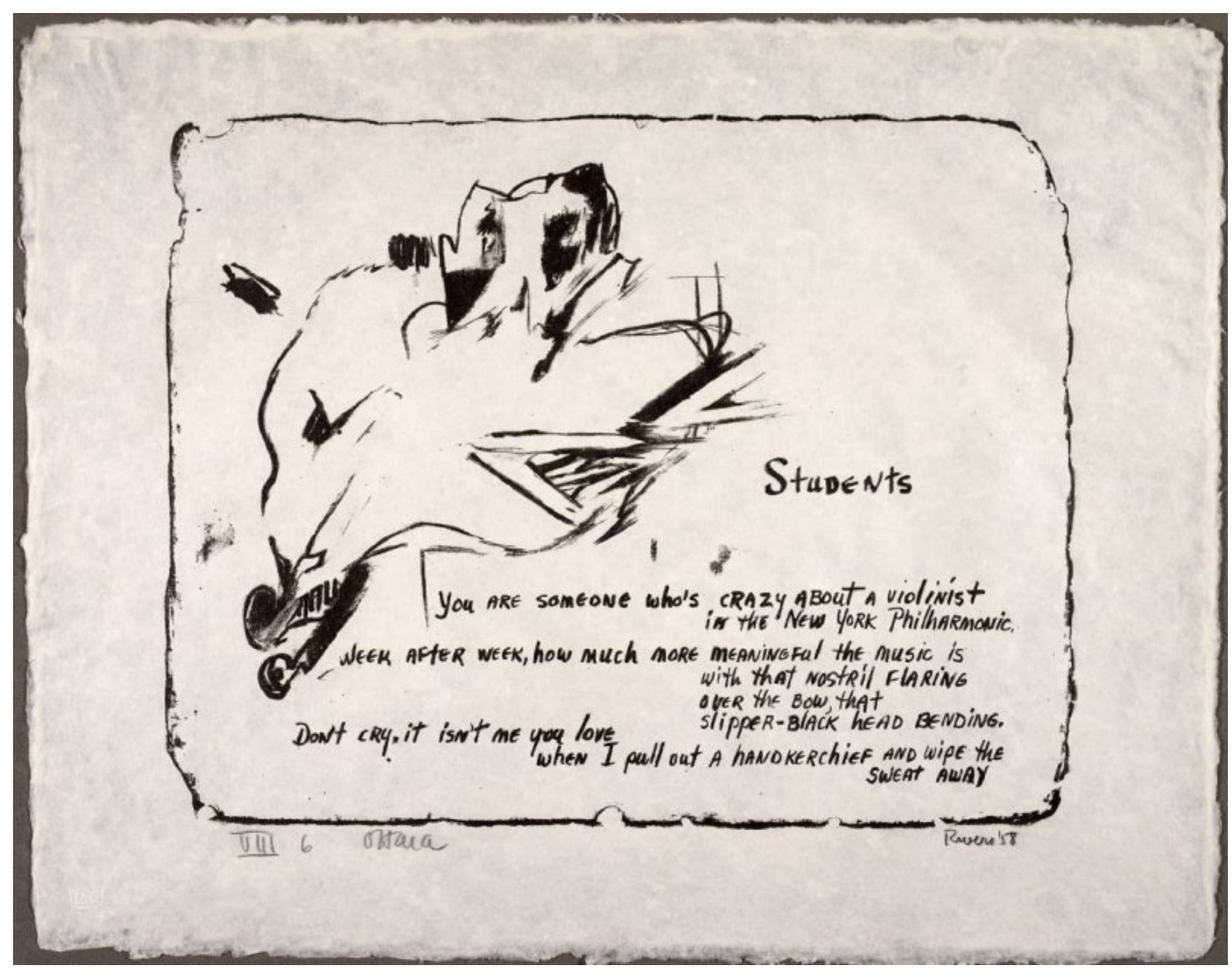

Fig. 6. Larry Rivers e Frank O'Hara. Música. Pedra 6 de Stones, 1957-60. Litografia, $19 \times 23$ 1/4 polegadas. Museu de Arte Moderna, Nova York. Doação do Sr. e da Sra. E. Powis Jones. 
Como de costume, aqui O'Hara corta os versos em junções estranhas, de forma que "um tesão fraco" pertence a "nas sombras" ao invés de "se agita uma planta". O tom é melancólico, triste, resignado. Essa estrofe, por sua vez, modula duas passagens escritas em dicção paródica: "onde a penumbra / cresce até feder / como a terra na lua", e "sem luz a flecha veste seu suspiro de abismo e suas mágoas de neve". A estranha tensão entre o verbal ["belas" imagens, rimas, sonoros sons vocais] e o visual [super homens de ombros largos, genitália gigante, um chapéu alto] cria uma visão delicadamente ambígua de Amor.

O leitor-observador é confrontado por sinais contraditórios que capturam a atenção.

Nem todas as Stones são tão interessantes como as três que eu abordei aqui. Springtemps, a segunda da série, consiste em um autocontido poema de O'Hara para Joseph Rivers à esquerda, e imagens borradas, semi-abstratas de flores, borboletas e corpos humanos à direita; nem a imagem nem o poema parecem ganhar muito com essa justaposição. Novamente, Música, a sexta pedra [Fig. 6] é, estritamente falando, um poema ilustrado, ao invés de um poemapintura. A metade inferior desta litografia reproduz o poema Students de O'Hara [1971, p. 290]; acima do texto, Rivers coloca o que ele chama de "sua própria versão do Batman: Violino-man". O próprio pintor pontua prudentemente que essa pedra "é um pouco mais à moda antiga: nosso estilo não integrado". Nesse caso, Frank já havia escrito o poema e pediu a Larry que respondesse. "Um bom poema", disse Rivers, "mas para o tipo de mente que eu tenho, inútil" [RIVERS, 1963, p. 96].

A questão aqui não é tanto saber se Rivers gostou do poema, mas de que se tratava de uma obra já finalizada, condição que deixa o pintor sem qualquer outro papel que não o de um ilustrador. A verdadeira colaboração artística deve, no entanto, envolver simultaneidade. Uma das mais encantadoras Stones é Melancolia Café [Fig. 7], que contém imagens semi-abstratas de itens do café da manhã como ovos, torradeira, queimadores a gás, frigideiras e uma mesa. Essas imagens são distorcidas como se sua visão tivesse sido borrada pela sonolência ou pela ressaca. Tudo na cena parece desconexo: nas palavras de O'Hara, "o ovo silencioso pensa / o ouvido da torradeira espera". A última linha resume tudo: "os elementos de descrença são muito fortes pela manhã". Aqui, poeta e pintor parecem estar na mesma frequência.

\section{8}




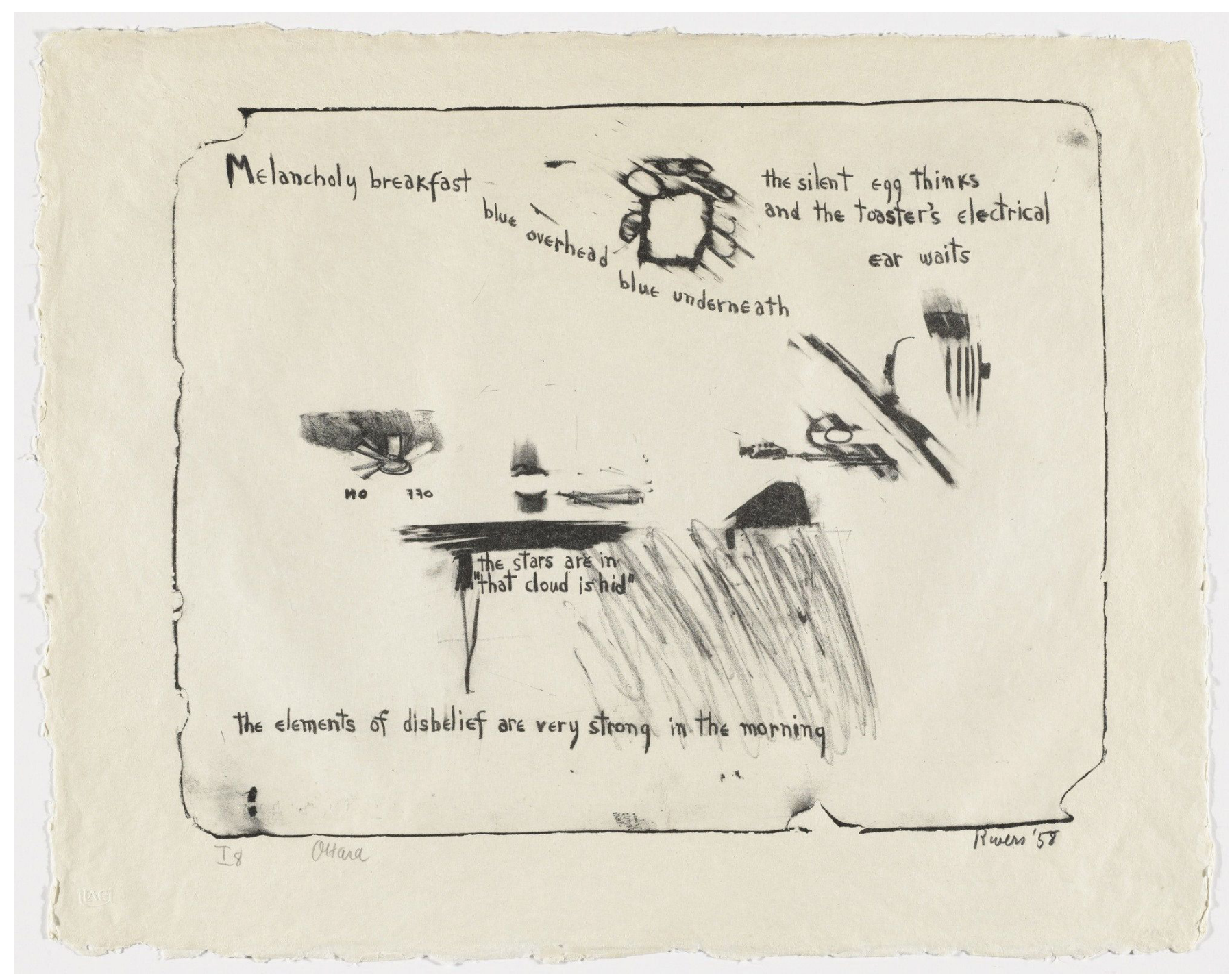

Fig. 7. Larry Rivers e Frank O'Hara. Melancholy Breakfast | Melancolia Café. Pedra 7 de Stones, 1957-60. Museu de Arte Moderna, Nova York Doação do Sr. e da Sra. E. Powis Jones. 
Passar de Stones a Poemapinturas - conjunto de colaborações realizadas por O'Hara e Norman Bluhm em $1960^{59}$ - é dar um salto rumo a um mundo pictórico muito mais lírico, delicado, efêmero, mas igualmente interessante. Bill Berkson descreve a gênese dos Poemapinturas da seguinte forma:
[Toti del Monte, a famosa soprano de 300 libras, cantando Madame Butterfly], eu disse a Frank: "Eu tenho todo esse papel, vamos colocá-lo na parede". Foi então que decidimos que gostaríamos de ouvir música e brincar com palavras e pintura. Mas não era um projeto sério. Apenas queríamos fazer alguma coisa enquanto a música rolava. Por exemplo, se ouvíamos uma sinfonia de Prokofiev, você poderia sentir as botas na minha pintura. [BLUHM, 1975]
Em uma triste tarde de domingo em outubro de 1960, o pintor Norman Bluhm e Frank O'Hara, poeta e autoconfesso balayeur des artistes, encontraram-se no ateliê de Bluhm no velho Edifício Tiffany da Park Avenue South, e como o péssimo tempo não estava ajudando nem os humores nem a conversação, decidiram embarcar em um projeto do qual já haviam conversado há algumas semanas. Horas depois, eles haviam feito esses 26 poemapinturas. [LOEB STUDENT CENTER ${ }^{60}$, 1967]
Bluhm insiste que a música era a força motriz por trás da colaboração. Italiano pelo lado materno, Bluhm quisera ser um cantor de ópera quando criança. Frank, por
Em uma crítica de Poemapinturas para a revista Art News, John Perreault sugere que os dois artistas criaram a série "de uma única tacada, em um frenesi de criatividade semelhante a dois monges Zen em uma extravagante dança das estações ${ }^{61 "}$ [PERREAULT, 1967, p. 11]. Na verdade, não foi bem assim que aconteceu. Em uma entrevista, Norman Bluhm me contou uma versão bem menos romântica: poeta e artista demoraram muitos dias [e não apenas algumas horas!] para completar a série de Poemapinturas. Em seguida transcrevo o seu relato:

Frank e eu gostamos de música. Costumávamos nos encontrar nos domingos pela manhã no meu ateliê, escutar música e conversar olhando para as pinturas, e então ir para a minha casa e escutar gravações. Um dia, ouvindo uma ópera sua vez, quisera ser um pianista em uma orquestra. Para ambos os artistas, a música era extremamente importante: eles acreditavam que todas as artes se relacionam e viam a separação moderna dos gêneros artísticos como algo desesperadoramente limitante.

Bluhm recorda que o trabalho com os Poemapinturas "foi um evento fantástico, um happening e uma forma de nos divertirmos. Eles foram feitos como um evento de duas pessoas que guardavam um sentimento especial uma pela outra e pela arte, pela música e pela literatura". Quanto à técnica, "as palavras são mais importantes que os gestos, então basicamente tentamos manter as artes como meros gestos [daí a decisão de utilizar 
apenas o preto e o branco], não uma ilustração do poema. A ideia era que o gesto se relacionasse, de forma abstrata, à ideia do poema. Raramente fazíamos uma coisa à la Dali, onde você recolhe o drip e joga ele no mundo".

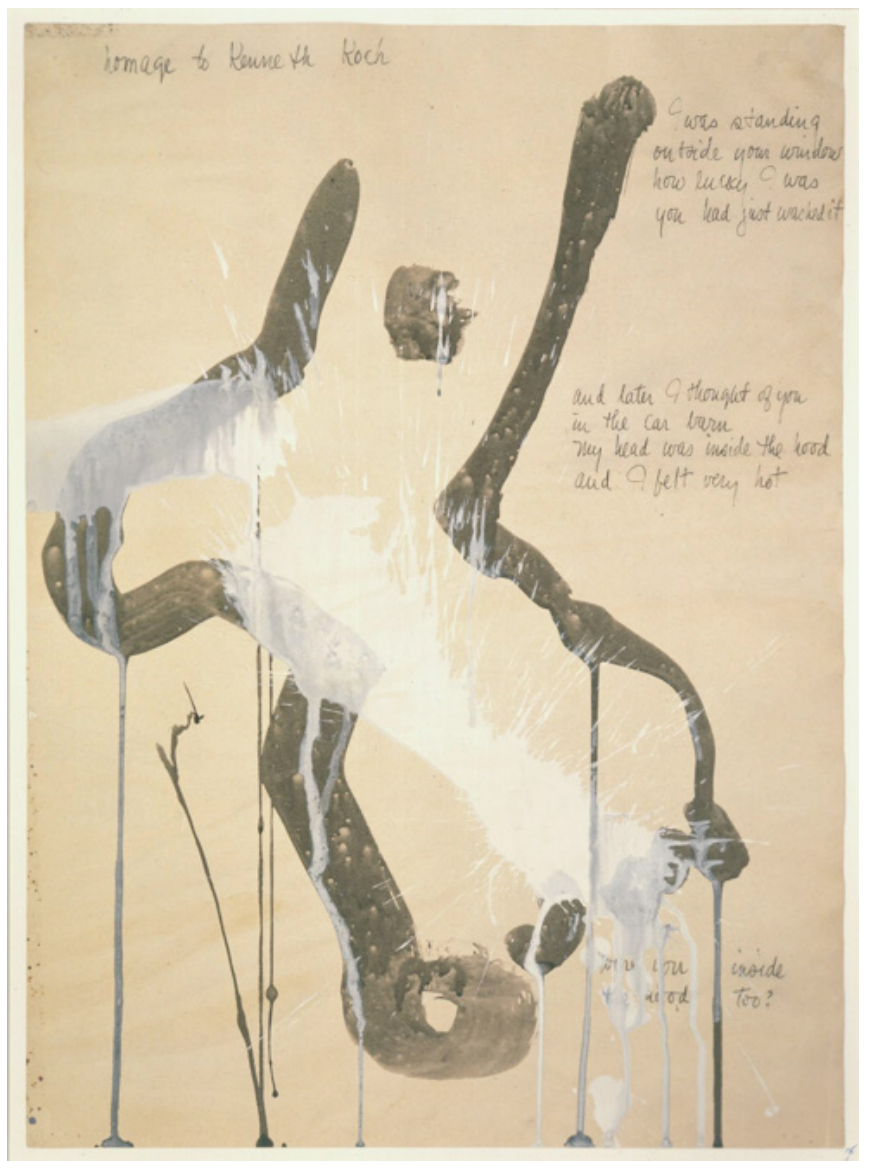

Fig. 8. Norman Bluhm e Frank O'Hara. Homenagem a Kenneth Koch. 1960.

Guache e nanquim, 19 1⁄2 × 14 polegadas. Coleção Universidade de Nova York.
Às vezes Bluhm fazia um desenho e O'Hara inventava um conjunto de palavras para aquele desenho; em outros casos, o procedimento era invertido. Mas cada poemapintura, Bluhm me contou, "surgiu de uma relação cômica com pessoas que conhecíamos, a partir de situações particulares. O tom era cômico ou satírico, numa espécie de ópera-bufa. Nós pensamos nossa colaboração como um evento teatral, um passatempo. Fizemos isso por diversão, esquecendo das misérias e dos casos amorosos - nossos problemas mais sérios". Vejamos, por exemplo, Homenagem a Kenneth Koch [Fig. 8]. A imagem dispõe uma longa forma abstrata gravada com tinta preta, com um drip espesso de tinta branca atravessando sua extensão. No canto direito, na bela caligrafia de O'Hara, lemos o seguinte poema:

\section{Parado de pé}

do lado de fora da sua janela

que sorte a minha

você tinha acabado de abri-la

mais tarde pensei em você

no estacionamento,

minha cabeça dentro do capô

fazia muito calor

você também estava dentro do capô? 
Esse poema encantadoramente absurdo, no qual dois amantes anseiam por um encontro dentro do capô escaldante de um carro, foi inspirado, de acordo com Bluhm, pelo seguinte incidente: "uma vez, nós [Kenneth Koch e eu] buscamos duas garotas em uma festa. Ele terminou com a mais bela das duas, mas ela tinha pés grandes. Eu contei a Frank sobre isso e desenhei a forma de um pé [a grande forma abstrata em tinta preta]". Frank respondeu escrevendo um tolo poema de amor, apropriado para a ocasião.

\section{we lcome to Kity Hawk}

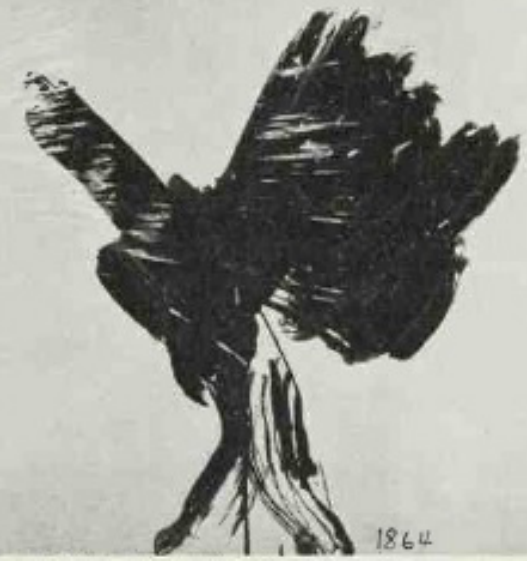

Fig. 9. Norman Bluhm e Frank O'Hara. Welcome to Kitty Hawk. Bem-vindo a Kitty Hawk

1960. Guache e nanquim, 19\% x 14". Coleção Universidade de Nova York.
Ou de novo, Bem vindo a Kitty Hawk[Fig. 9] evidentemente surgiu de uma conversa sobre aviões. "Meu pai", lembra Bluhm, "era um aviador, e eu contei para o Frank uma história de um mecânico que construiu seu próprio avião e quando ele atingiu 200 pés, a engrenagem partiu e o avião bateu". Essa não é exatamente uma história feliz, mas a forma negra que Bluhm desenha [ele a chama de um mau avião] parece um falcão. Da mesma forma, o texto de O'Hara é muito divertido.

Poucos dos Poemapinturas contêm poemas de fato. O Poemapintura n. 3 ostenta a única palavra Busto; o n. 6 apresenta as letras b-a-n-g nos quatro cantos da tela, ao redor de uma figura que parece um cômico falo peludo. Muitos Poemapinturas não são mais que piadas internas: o n. 19 se refere a Chicago por se tratar do local de nascimento de Bluhm; n. 13 contém a frase "vende-se morbidade", que como Bill Berkson afirma, se refere à década em que Bluhm viveu em Paris. o Poemapintura n. 5, que não contém imagens visuais, é praticamente uma transcrição direta de uma conversa de O'Hara: as palavras "estou tão cansado de todas as festas, parece janeiro e suas ressacas à beira da praia" encontram-se rabiscadas pela superfície da imagem.

Individualmente, esses Poemapinturas podem parecer irrelevantes - uma ou duas pinceladas 
de tinta, algumas linhas e jatos recurvados, e uma frase como "colhendo e plantando/plantando e colhendo... Skylark", como no de número 1. Mas John Perreault está certo ao comparar essas colaborações às "pegadas de um ballet selvagem"63 [PERREAULT, 1967, p. 11]. Como desenhos nanquim chineses, a série possui um charme lírico um tanto diferente do tom sutil e complexo de Stones. Por um lado, O'Hara agora tem a chance de apresentar sua bela caligrafia, aspecto que a técnica de produção de litografias havia tornado impossivel, forçando o poeta a utilizar letras de imprensa. A combinação das letras cursivas de O'Hara com os desenhos ondulados, com formas de ferradura e densas manchas de tinta branca de Bluhm - sugerindo gestos fugazes - fazem da série de Poemapinturas verdadeiras obras de arte mesmo se suas mensagens dificilmente os qualificam como "poemas". Mão, por exemplo [Fig. 10], apresenta a forma de um punho fechado, contornado por grossas camadas de preto, com um respingo de branco na parte central da tela. A palavra hand aparece no canto superior esquerdo. Cada um dos cinco "dedos" contém uma pequena e delicada escrita:

\author{
Você come toda hora, \\ você até sabe como usar \\ os hashis \\ então porque você não me escreve \\ uma carta \\ esquece
}

O "esquece" que fecha o poema é posicionado dentro do polegar, de forma que ao chegarmos ao último dedo, também chegamos ao final do pequeno poema Dada de O'Hara com seu endereçamento ingênuo à mão de alguém. Tomado em si mesmo, trata-se de um poema trivial, mas a disposição de palavras e frases dentro dos grossos contornos pretos em forma de dedos e o contraste entre preto e branco criam uma interessante configuração espacial. De fato, as 26 colaborações deveriam ser tomadas antes como partes de um todo integrado - um evento total - do que como pinturas separadas. Sua inventividade, sagacidade e encanto vão aparecendo à medida que estudamos a relação do gesto ao gesto, da pegada à impressão digital, da frase lírica à palavra de quatro letras, do provérbio à insinuação sexy, dos respingos brancos sobre a tela às negras letras em nanquim, e assim por diante. 
As "colaborações" dos anos 1960 com artistas como Joe Brainard e Jasper Johns não são, em sentido estrito, poemapinturas. A colagem em papel e tinta sem título [Fig. 11], por exemplo, é uma da série de vinte e poucos quadrinhos Pop que O'Hara fez com Joe Brainard entre 1963 e $1966^{64}$. Ela combina papéis de parede cafona nas cores azul-e-branco com pedaços de uma nota de um dólar com a figura de George Washington, um ticket para o Metrô de Paris, uma peça de bloco de notas, cartas com o endereço da $9^{\text {th }}$ Street, e bem no centro, uma página dos quadrinhos Nancy com um balão onde se lê: "quer uma coca?" Embora divertidas, as justaposições são bastante óbvias. Perde-se aqui intrincado contraponto verbo-visual de Stones ou o frágil lirismo dos Poemapinturas. Nesses quadrinhos, voltamos ao mundo de Picabia e Schwitters: a Colagem Nancy é uma montagem interessante, mas que tenta e alcança menos do que as colaborações anteriores de O'Hara.
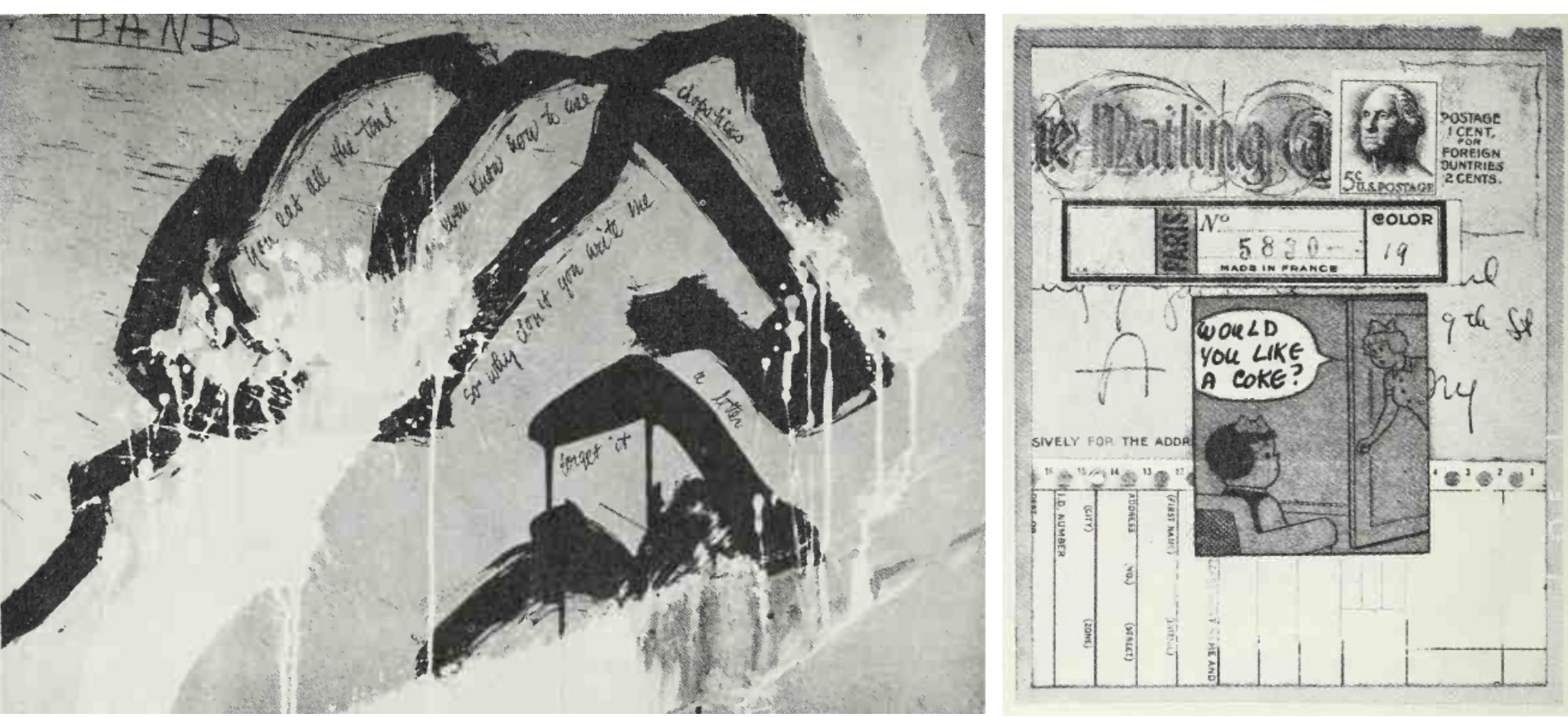

Fig. 10. Norman Bluhm e Frank O'Hara. Hand | Mão, 960. Guache e nanquim. 19 1/4 x 14 polegadas. Coleção Universidade de Nova York. Fig. 11. Joe Brainard e Frank O'Hara. Sem tífulo. 1964. Colagem e nanquim sobre papel, $10 \times 8$ polegadas. Coleção do Espólio de Frank $\bigcirc$ 'Hara. 


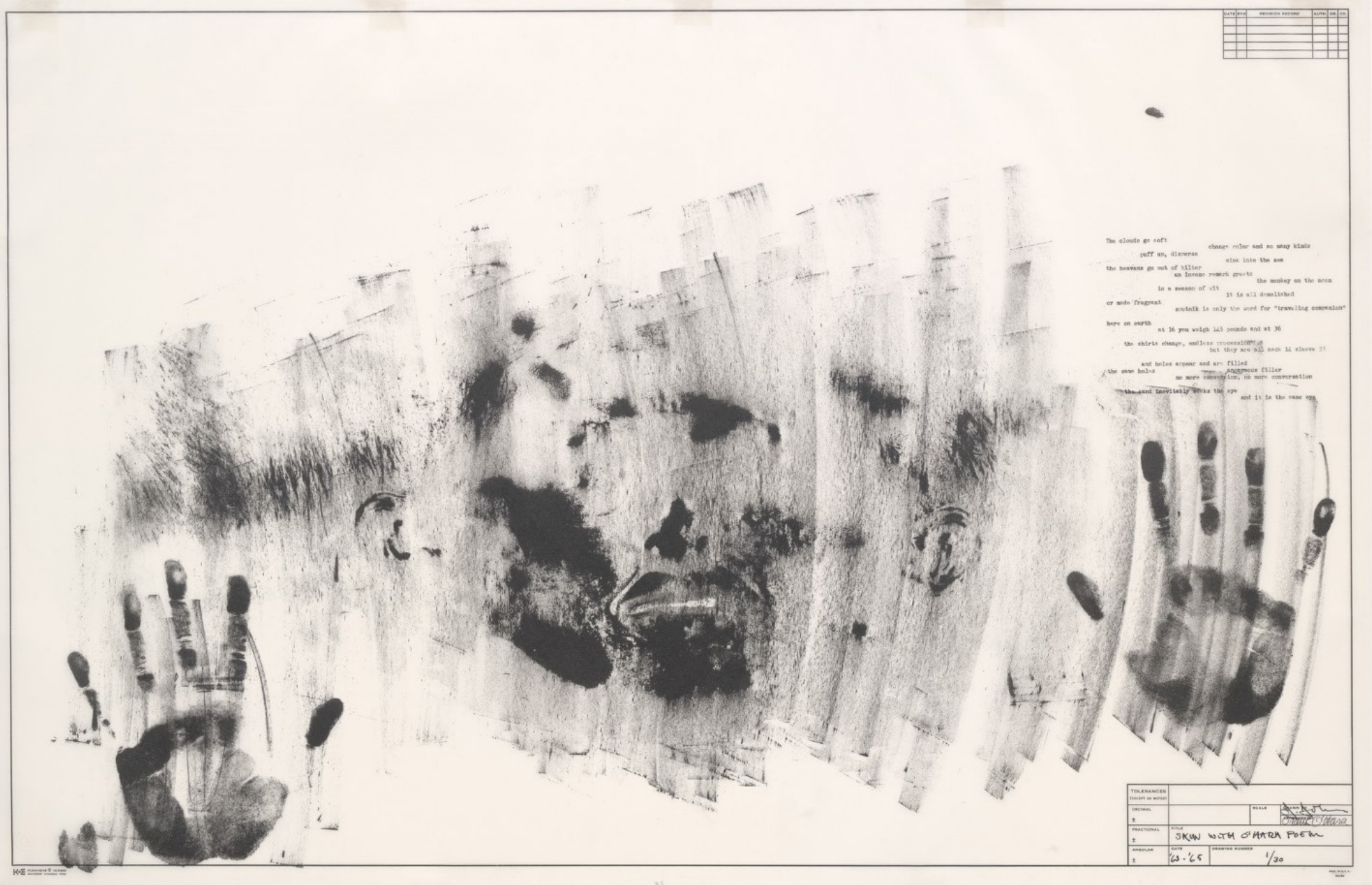

Fig. 12. Jasper Johns. Skin with O'Hara Poem | Pele com Poema de O'Hara. 1963-1965.

Litografia, impressão em tinta preta, 22 X 34 polegadas. Museu de Arte Moderna, Nova York.

Doação da Fundação Celeste e Armand Bartos. 
A conhecida obra de Jasper Johns Pele com Poema de O'Hara [1963-65] nos retira definitivamente do campo dos poemapinturas [Fig. 12]. A litografia contém as impressões digitais de duas mãos, uma de cada lado. No centro, encontram-se duas formas escuras borradas, sugerindo contornos faciais; borrões pretos atravessam a superfície conectando as mãos às formas faciais. Sobre a mão direita, Johns reproduziu o texto de As nuvens amolecem [O'HARA, 1971, p. 474], datilografado em escala menor. Os últimos versos a parecem levemente recobertos por manchas pretas. O poema toma parte no jogo de achado-e-perdido: ora o vemos [embora à primeira vista o observador mal se dê conta da sua existência] ora não o vemos mais. É uma composição excitante, combinando a figuração realista e o jogo Dada, mas trata-se de uma tela elaborada por Jasper Johns, não uma colaboração. Previamente executado, o poema é usado como parte de uma estrutura espacial65.

Podemos então concluir que o poemapintura, no sentido de uma colaboração genuína, apresenta desafios e dificuldades incomuns para o artista. Peter Schjeldahl66 o chama de um "exótico híbrido de dois dos mais solitários e tradicionalmente 'belos' gêneros das artes", e Bill Berkson ${ }^{67}$ observa: "colaboração entre dois artistas sérios [mesmo no melhor dos espíritos] envolve sempre algum tipo de competição. A tarefa pode pouco a pouco desandar em uma corrida para estar sempre um passo à frente. Pintando uma grossa linha preta no meio da folha, o artista A dá a entender ao artista B que ele sabe o que a musa de B está aprontando e lhe pede desculpas pela sujeira" [BERKSON, 1960].

O presente capítulo concentrou-se na produção de O'Hara enquanto "poeta entre pintores". Para dar cabo desta tarefa, acabei negligenciando suas colaborações com compositores, coreógrafos e cineastas. Sem dúvida, filmes como A última camisa limpa [The Last Clean Shirt], de Alfred Leslie, para o qual O'Hara escreveu legendas a fim de criar um duplo cenário, ou o texto que ele providencia para os Quatro Diálogos [Four Dialogues] de Ned Rorem merecem estudos aprofundados. Mas a pintura possui um lugar especial no universo poético de O'Hara, de forma que busquei enfatizar seu lugar no desenvolvimento artístico do poeta. O próprio O'Hara traçou as distinções cruciais em uma carta escrita a Gregory Corso em 1958:

Muitas pessoas que você conhece andam por perto ultimamente, Kerouac - que eu só vi uma ou duas vezes, mas de quem gostei muito - Howard Hart e [Philip] Lamantia estão lendo com um trompetista francês e se chamam de Jazz Poetry Trio... Eu não entendo bem o seu estímulo pelo jazz, mas é provavelmente o mesmo que sinto pela pintura... quero dizer, você não pode 
estar dentro o tempo todo, fica tudo muito chato e você não pode se dar ao luxo de ficar entediado com poesia, então você arranja um entusiasmo secundário como símbolo do primeiro - por exemplo, percebo que o que Kerouac e "eles" sentem como o conteúdo do jazz em relação ao seu próprio trabalho [aspirações], eu sinto pela pintura com a diferença correspondente em termos de aspiração. Quero dizer que onde eles têm o Bird [Charlie Parker] como inspiração, eu tenho Bill de Kooning: em parte porque sinto que o jazz é bonito o bastante ou até bonito demais, mas não cruel o suficiente; em parte porque onde o jazz é fugaz [no tempo] e portanto comovente, de K é derradeiro, e portanto trágico... Além disso, eu não preciso ver o que eu admiro enquanto eu escrevo e também preferiria não ouvi-lo, o que parece ser inevitável com o jazz uma vez que mesmo que eles não assoviem enquanto trabalham eles leem com jazz. Talvez eu devesse tentar fazer uma leitura em algum lugar de frente para um Pollock ou um de K... Acho que meu ponto é que a pintura não se intromete na poesia ${ }^{68}$. [O'HARA, 1958]

Ler um poema de frente para um De Kooning: esse é o tipo de aspiração que esperamos de O'Hara. Mas note que ele não deseja que a pintura "se intrometa na poesia", permanecendo como seu "entusiasmo secundário". Quando perguntado por Lucie- Smith se ele alguma vez já quis ser pintor, O'Hara respondeu que não, mas admitiu "brincar" com a pintura toda vez que se encontrava esperando por alguém em um ateliê. "Eu posso fazer alguma coisa pequena, sabe? Mas eu nunca fiz algo realmente sério porque... me parece que a pintura e a escultura exigem tanta concentração durante um período tão grande de tempo que não tenho certeza se eu posso fazer isso, ao passo que é possível escrever relativamente rápido" [O'HARA, 1975, p. 21].

O que isso significa? Nada além do fato de que o talento particular do poeta não estava para a pintura. Certamente a afirmação de que a pintura é mais difícil e consome mais tempo que a escrita poética é irônica, pois muitos pintores do Abstracionismo e da Pop Art com quem O'Hara convivia dificilmente exerciam a "concentração" durante longos períodos de tempo à qual ele se refere aqui. E em todo caso, a pergunta "Por que você não é um pintor?" deve ter soado maravilhosamente absurda a O'Hara. Sua pseudo-resposta a essa pergunta sem sentido se tornou o tema de um de seus maiores poemas:

\section{PORQUE EU NÃO SOU UM PINTOR}

Não sou pintor, e sim poeta.

Por quê? Acho que eu preferiria

ser pintor, só que não sou. Bem,

por exemplo, o Mike Goldberg

está começando um quadro. Vou lá.

"Senta e bebe alguma coisa", ele 
diz. Bebo. Bebemos. Eu olho

pro quadro. "Você escreveu SARDINHAS."

"Tinha que pôr alguma coisa ali."

"Ah." Os dias passam e eu

vou lá de novo. O quadro avança,

eu vou embora, e os dias vão

passando. Eu volto. $\bigcirc$ quadro está

pronto. "Cadê SARDINHAS?"

Só ficaram umas

letras. "Era demais", diz Mike.

Mas e eu? Um dia eu penso numa

cor: laranja. Escrevo um verso sobre

laranja. E logo é uma página

inteira de palavras, não versos.

Depois outra página. Devia

haver muito mais, não laranja, mas

palavras, sobre o horror do laranja e

da vida. Os dias passam. Está até

em prosa, sou poeta mesmo. Meu poema

está pronto, e ainda nem falei em

laranja. Doze poemas, e o nome é

LARANJAS. E um dia numa galeria

vejo o quadro do Mike: SARDINHAS.
Com alguma frequência, as leituras desse poema costumam supor que O'Hara está enfatizando diferenças: um pintor como Mike Goldberg está constantemente "retirando", até que nada reste das sardinhas a não ser as letras, ao passo que o poeta continua "acrescentando". Mas numa segunda leitura, torna-se evidente que o poema é uma grande piada. Se alguém faz uma pergunta estúpida, O'Hara sugere que merece uma resposta estúpida. Pois de fato, a arte de Frank revela-se igual à de Mike. Se a pintura de Mike não contém sardinhas ao final, também as "Laranjas" de Frank nunca mencionam a palavra "laranja". Em ambos os casos, a palavra ou imagem original é o mero gatilho para uma cadeia de associações que em último caso levam diretamente à sua própria destruição. O'Hara é um poeta e não um pintor por nenhuma outra razão senão a de que é isso que ele é. Mas, sem dúvida, o poema também diz que a poesia e a pintura são partes do mesmo espectro, que em uma análise final sardinhas e laranjas são uma mesma coisa. É por isso que o dispositivo retórico governando o poema é a repetição ["Bebo. Bebemos"; "Eu vou embora e os dias vão passando"; "Eu vou lá de novo; Eu volto"]. Se a arte não tolera divisões, é porque deve ser vista como processo, não como produto. 
7 A tradução para o português dos poemas ainda inéditos de O'Hara citados por Perloff se deu, sempre que possível e respeitando as interpretações da autora, como um exercício de transcriação. Se por um lado era o nosso desejo enquanto tradutores aproximar o universo $\mathrm{O}^{\prime}$ Hariano do leitor bra-

1 Art in America, v. 53, Out./Nov. 1965, p. 24.

2 Cf. Prefácio de In Memory of My Feelings. A Selection of Poems by Frank O'Hara, ed. Bill Berkson, Nova York: Museum of Modern Art, 1967.

3 Cf. Art News, 66 [jan. 1968], 68. Cf. John Button, "Frank's Graça," Panjandrum, 2 \& 3 [1973]: "O seu trabalho no MoMA foi tirando cada vez mais do seu tempo livre, tempo esse que poderia estar se dedicando à poesia".

4 "Four Apartments," p. 291. Cf. James Schuyler, Art News, 73, maioe 1974, 45: "Frank precisava de um trabalho e sua paixão pelo museu não tinha ressalvas... além disso, ele era extremamente organizado, com uma memória exemplar".

5 Em diversos poemas, O'Hara faz alusões à Cedar Tavern, bar e restaurante da região de Greenwich Village, Nova York, que servia como local de encontro entre artistas de vanguarda e escritores da cidade, em especial pintores do Expressionismo Abstrato e poetas da geração Beat. [Nota da Tradução].

6 Graça Hartigan escreve em uma carta à Bruce Boone, editor do número especial da Panjandrum dedicada à $\bigcirc^{\prime}$ Hara: " $\bigcirc$ fato de Frank ser homossexual sempre foi algo compreensível para mim - eu amo os homens, porque ele não amaria? Isso nunca interferiu - o que poderia interferir? - no amor que sentíamos um pelo outro. Não sou a primeira pessoa a dizer que sexo não é necessariamente amor, ou viceversa". Em uma entrevista ao mesmo autor conduzida em 25 de novembro de 1975, Graça Hartigan deu o mesmo argumento. Entre 1951 e 1960, ela e Frank se viam ou falavam pelo telefone praticamente todos os dias. sileiro, por outro, interessa apostar na potência da tradução como dispositivo de endereçamento. Acreditamos que isso se encontra em consonância com a proposta poética de $\mathrm{O}^{\prime} \mathrm{Ha}$ ra, marcada pela ênfase no procedimento e na imbricação entre arte e vida. Assim, seguindo a doutrina do Manifesto Personism - it puts the poem squarely between the poet and the person - tentamos colocar a tradução no espaço preciso entre nós e o poeta. Quando possível, utilizamos traduções já publicadas dos poemas, sempre com os créditos devidos. Os poemas originais em inglês encontram-se nas notas de fim. [Nota da Tradução]

8 No original: Grace, / you are the flowergirl on the candled plain / with fingers smelled of turpentine

9 No original: Grace destroys/ the whirling faces in their dissonant gaiety where it's anxious, / lifted nasally to the heavens which is a carrousel grinning/ and spasmodically obliterated with loaves of greasy white paint and this becomes like love to her, is what I desire/ and what you, to be able to throw something away without yawning/"Oh Leaves of Grass! o Sylvette! oh Basket Weavers' Conference!" / and thus make good our promise to destroy something but not us.

10 Nesse ponto, a autora faz uma alusão ao ensaio Eros the Bittersweet, de Anne Carson. [Nota da Tradução].

11 Tradução de Ricardo Domeneck publicada na revista Modo de Usar. Disponível em: http://revistamododeusar.blogspot.com/2010/03/frank-ohara- 1926-1966-postagem.html Acesso em: 20/06/2021. 
12 Em uma carta ao autor em 10 de fevereiro de 1976, Graça Hartigan identifica a primeira pintura como Ocean Bathers [1953], coleção de Muriel Newman, Chicago, e a segunda como Frank O'Hara and the Demons [1952], coleção particular de Graça Hartigan. Hartigan percebe que ambas as pinturas tentam captar a "postura habitual do corpo de Frank".

13 No original: Yes/like the still center of a book on Joan Miró/blue red green and white/ a slightly over-gold edition of Hart Crane/ and the huge mirror behind me blinking, paint-flecked/they have painted the ceiling of my heart/and put in a new light fixture/ and Arte Contemporáneo by Juan Eduardo Cirlot/ and the Petit Guide to the Musée National Russe/it is all blankly defending its privacy/from the sighing wind in the ceiling/ of the old Theatre Guild building/ on West 53d Street / near the broken promises of casualness/ to get to the Cedar to meet Grace/ I must tighten my moccasins/ and forget the minute bibliographies of disappointment/ anguish and power/ for unrelaxed honesty/this laissez-passer for chance and misery, but taut/ a candle held to the window has two flames/and perhaps a horde of followers in the rain of youth / as under the arch you find a heart of lipstick or a condom/left by the parade/ of a generalized intuition / it is the great period of Italian art when everyone imitates Picasso

afraid to mean anything/ as the second flame in its happy reflecting ignores the candle and the wind. A tradução do poema no corpo do ensaio limitou-se aos versos citados pela autora.

14 No original: Why do you play such dreary music/on Saturday afternoon, when tired/ mortally tired / long for a little/ reminder of immortal energy? / / All/ week long while / trudge fatiguingly/from desk to desk in the museum/ you spill your miracles of Grieg/ and Honegger on shut-ins. // Am I not/ shut in too, and after a week/ of work don't I deserve Prokofieff? //
Well, I have my beautiful de Kooning/ to aspire to. I I think it has an orange/ bed in it, more than the ear can hold.

15 No original: The eyelid has its storms. There is the opaque fish-/ scale green of it after swimming in the sea and then sud-/ denly wrenching violence, strangled lashes, and a barbed/wire of sand falls to the shore.

16 Em 8 de abril de 1957, O'Hara escreveu para Helen Frankenthaler em uma carta não publicada: Eu estou finalizando um poema que escrevi recentemente e queria saber se posso usar o seu título nele [Blue Territory]. Mas, por favor, se você não gostar ou se a associação te incomodar de alguma forma...por favor, me diga e eu posso mudar para "Boo Titulary" ou algo do gênero... também sempre posso recorrer simplesmente à "Poem", como já fiz no passado. Em 25 de setembro de 1964, numa sessão de leitura de poesia no Buffalo, gravada por Donald Allen, antes de ler "Blue Territory", O'Hara conta que a ideia do poema surgiu quando viu no Whitney a enorme pintura abstrata de Helen Frankenthaler de mesmo nome, embora ele não soubesse muito bem porque isso aconteceu.

17 Preferimos manter como no original tone poem, por acreditamos que a possível tradução de poema sinfônico/musical poderia indicar outros sentidos [Nota da Tradução].

18 Dada, Surrealism, and Their Heritage [Nova York: Museu de Arte Moderna, 1968], p. 148. Ver também Diane Waldman, Joseph Cornell [Nova York: Braziller, 1977].

19 No original: Now that our hero has come back to us/in his white pants and we know his nose trembling like a flag under fire, / we see the calm cold river is supporting/ our forces, the beautiful history. / / To be more revolutionary than a nun/is our desire, to be secular and intimate/ as, when sighting a redcoat, you smile/ and pull the trigger. Anxieties / and animosities, flaming and feeding// on theoretical 
considerations and/ the jealous spiritualities of the abstract/ the robot? they're smoke, billows above/ the physical event. They have burned up./ See how free we are! as a nation of persons. / / Dear father of our country, so alive/ you must have lied incessantly to be/immediate, here are your bones crossed/ on my breast like a rusty flintlock, / a pirate's flag, bravely specific// and ever so light in the misty glare of a crossing by water in winter to a shore/ other than that the bridge reaches for./ Don't shoot until, the white of freedom glinting/ on your gun barrel, you see the general fear.

20 Tradução de Adelaide Ivánova publicada no Suplemento Pernambuco. Disponível em: http://www.suplementopernambuco.com.br/edi\%C3\%A7\%C3\%B5es-anteriores/78-traducao/1679-dois-poemas-pol\%C3\%ADticos-de-frank-o-hara.html. Acesso em: 20/06/2021.

21 No original: - / dress in oil cloth and read music/ by Guillaume Apollinaire's clay candelabra.

22 Ver, por exemplo, Design Etc., [O'HARA, 1975, p. 33] e Apollinaire's Pornographic Novels [O'HARA, 1975, p. 156-159]. Nessa entrevista, de 25/11/1975, Grace Hartigan me confessou que Frank costumava dizer que ele não queria viver mais do que Apollinaire havia vivido. $\bigcirc$ poeta francês morreu aos 40 anos, e, numa estranha coincidência, o mesmo aconteceu com $O^{\prime}$ Hara.

23 APOlliNAIRE, Guillaume. Apollinaire on Art, Essays and Reviews 1901 - 1918, Coleção The Documents of 20th Century Art. Nova York: Viking, 1971, p. xxix.

24 Ensaio publicado na revista Kulchur, v. 3, no. 9 [Primavera 1963]. In: O'HARA, Frank. Standing Still and Walking in New York. Bolinas, Calif.: Grey Fox Press, 1975, p. 140.

25 O conceito de flat sculptures diz respeito às icônicas pinturas de Alex Katz, realizadas geralmente em fundos monocromáticos, sejam eles brancos ou em cores vivas, e na ausência de tridimensionalidade nos retratos e paisagens, enfatizando o esquema de estrutura plana da composição. [Nota da Tradução] 26 John Canaday era crítico de arte do Times; Emily Genauer escrevia para o Herald Tribune. Sobre ambos, O'Hara escreveu: "[...] em todas as temporadas, ambos reservavam uma semana, no mínimo, para se dedicarem à escrita de colunas inteiras que falassem sobre suas dificuldades físicas de locomoção até as galerias. O senhor Canaday nitidamente não se cansava de lamentar o transporte público da Madison Avenue e a senhora Genaver, à procura do Delancey Street Museum, sendo auxiliada pelo serviço de táxi e dos balconistas das lojas de delicatessen em sua franca apreciação de um safari tão distante quanto a Houston Street. Nenhum deles parece ter um senso de direção melhor do que o artístico. Junto disso a especialidade do senhor Canaday tem sido a sagaz desconfiança da estratégia de lobo em pele de cordeiro, uma estratégia destinada exclusivamente aos expressionistas-abstratos que possuem a mesma crença simplista, de que, aparentemente, nenhum artista figurativo jamais tenha desejado vender uma pintura" [O'HARA, 1975, p. 144-145].

27 Cf. APOLLINAIRE, Guillaume. "Watch Out for the Paint! The Salon des Independants. 6,000 Paintings are Exhibited" [1910], In: APOLLINAIRE, Guillaume. Apollinaire on Art, Essays and Reviews 1901 - 1918, Coleção The Documents of 20th Century Art. Nova York: Viking, 1971, pp. 64-65.

28 Ver Amy Golden, Art in America, v. 63, mar.-abr. 1975, p. 41; Eleonor Dickinson, San Francisco Review of Books, v. 1, n. 4 [A 1975], 6, p. 18-19. Eu parto da opinião inversa em minha resenha de A Cin The New Republic, v. 1, mar. 1975, p.23-24.

29 Set piece se refere à composição artística, literária ou não que possui atribuições ordenadas e especificadas numa estrutura fixa. [Nota da tradução] 
Cf. Introdução ao catálogo da exposição New Spanish Painting and Sculpture. Nova York: Museu de Arte Moderna, 1960, p. 10.

31 Cf. Art News, v. 52, dez. 1953, p. 42.

32 Cf. Art News, v. 53, jan. 1954, p. 64.

33 Indizível - unspeakable - é termo utilizado de forma recorrente na crítica literária norte-americana para se referir à obra do escritor Henry James. Em livros como A outra volta do parafuso, o estilo do prosador - reconhecido por suas histórias de terror - se caracteriza por limitar o relato 'físico' dos eventos da narrativa, de forma a dar espaço para que a imaginação do leitor possa cocriar as cenas de horror, imaginando o indizível. [Nota da Tradução]

34 Cf. Art News, v. 54, fev. 1955, p. 53.

35 Cf. Art News, v. 53, abr. 1954, p. 47.

36 Ver, por exemplo, Allen Weller, Art Journal, 20 [Outono 1960], 52-56. Ressalvas semelhantes podem ser feitas sobre o curto ensaio de O'Hara "Jackson Pollock 1912- 1956". Em New Images of Man, O'Hara chama as pinturas preto-e-branco de Pollock feitas em 1951 de "ideografias de um mundo subjetivo que não conhecemos [...] os Cantos de Maldoror da arte norte-americana". Cf. New Images of Man, ed. Peter Selz [Nova York: Museu de Arte Moderna, 1959, p. 123-128]. 37 Horizon, de Set. 1959, publicado também em Art Cronichles, 106-120. Em entrevista televisiva de O'Hara com David Smith, o poeta identifica na vida de Smith "a tragédia americana ao contrário" porque Smith foi "um herói à la Henry James que ao invés de ter sido corrompido pela Europa, conseguiu influenciá-la", um "Thomas Wolfe, cujos sonhos estranhamente se realizaram." A entrevista sugere que Smith não via nada de "abstrato" em suas esculturas. Ele as entende como "femininas", dizendo "Eu gosto da presença desse ar feminino, por isso não faço figuras masculinas". O'Hara, então, the responde: "elas parecem amigas que vieram para Nova York. Estão aliviadas só de não estarem mais no meio do caminho." Barnett Newman foi entrevistado para a mesma série.

38 Cf. Sam Hunter, Larry Rivers, com uma Memória por Frank O'Hara e uma Declaração do Artista, exposições do Poses Institute of Fine Arts, Brandeis University, Waltham, Mass., 1965. Hunter traça uma breve cronologia [p. 45-46], e sua introdução é bastante útil.

39 Cf. Sam Hunter, Larry Rivers, p. 20.

40 Rivers utiliza a expressão smorgasbord, uma espécie de buffet livre sueco em que uma refeição inteira é servida em vários pratos.

41 Larry Rivers escreveu: "seu longo e maravilhoso poema Second Avenue, de 1953, foi escrito no meu ateliê de gesso, olhando essa avenida de cima. Uma madrugada eu estava trabalhando em uma escultura dele. Entre as poses, ele terminava o seu longo poema. Três policiais gordos viram a luz acesa e subiram para fazer aquela cena 'você chama isso de arte? o que você tá fazendo aquie?' que todo artista de Nova York já deve ter vivenciado." Cf. Life Among the Stones, Location [Primavera, 1962]; e também em The Collected Poems of Frank O'Hara, [O'HARA, 1971, p. 529].

42 No original: Candidly. The past, the sensations of the past. Now! / in cuneiform, of umbrella satrap square-carts with hotdogs/and onions of red syrup blended, of sand bejewelling the prepuce/ in tank suits, of Majestic Camera Stores and Schuster's, / of Kenneth in an abandoned storeway on Sunday cutting even more/insinuating lobotomies of a yet-to-be-more-yielding world/ of ears, of a soprano rallying at night in a cadenza, Bill, of/ "Fornications, la! garumph! tereu! lala la! 
vertigo! Weevy! Hah!", / of a limp hand larger than the knee which seems to say "Addio" / and is capable of resigning from the disaster it summoned ashore. / Acres of glass don't make the sign clearer of the landscape/less blue than prehistorically, yet less distant, eager, dead!

43 No último verso do poema original - less blue than prehistorically, yet less distant, eager, dead! - a palavra blue remete tanto à cor azul - predominante na 2nd Avenue de Rivers, a que a autora se refere - como à tristeza da paisagem. [Nota da tradução]

44 A autora sugere uma brincadeira entre os sentidos do termo after, que pode ser tanto um indicativo de tempo - poemas depois de pinturas - como de sequencialidade - poemas em seguida a pinturas - ou de homenagem - poemas em homenagem a pinturas [Nota da Tradução].

45 Ver Roger Shattuck, Guillaume Apollinaire [Nova York: New Directions, 1971], p. 18-20.

46 Reproduzido em Rubin, Dada, Surrealism and their Heritage, 1967, p. 27-28.

47 Motherwell, The Dada Painters and Poets, An Anthology, tradução de Ralph Manheim. Nova York: Wittenborn, Schultz, Inc., 1951, p. 62

48 Ibid., p. 56, 274. Em The Grand Manner of Motherwell [1965], O'Hara escreve: "Eu conheci

Motherwell pela primeira vez em East Hampton, provavelmente no ano de 1952. Quando conversamos mais tarde, era sempre sobre poesia: Apollinaire, Baudelaire, Jacob, Reverdy, Rilke [não muito], Lorca [um monte], e também chegamos a conversar sobre Wallace Stevens e William Carlos Williams. Eu ficara extremamente impressionado pela série de Documentos da Arte Moderna [Dada Painters é o no 8 da série] que Motherwell havia editado [na verdade, eles eram o meu evangelho e o de muitos outros poetas]". O'Hara, Frank. Standing still and walking in New York. Bolinas, Califórnia: Grey Fox Press, 1975, p. 176.

49 Rubin. Dada, Surrealism, 1967, p. 96, prancha 129.

50 Conforme o artigo de Lippard "Max Ernst: Passed and Pressing Tensions", Hudson Review, 23 [Inverno 1970-71] ; rpt. Art Journal, 33 [Outono 1973], 12.

51 Trecho citado por Lippard em Max Ernst, 1970, p. 12.

52 Lippard, 1970, p. 14.

53 RIVERS, Larry. Location: Spring 1963. New York: Longview Foundation, 1963.

54 Em The Skin of the Stone, ensaio do livro The Scene, Reports on Post-Modern Art, Tompkins oferece um esboço biográfico muito interessante de Tatyana Grossman e discute Stones assim como outras colaborações realizadas em sua oficina. Para mais informações ver também GRAY, Cleve. "Tatyana Grossman's Workshop". In: Art in America, 53, Dez./Jan. 1965-1966, p. 83; e MITGANG, Herbert, "Tatyana Grossman, the inner light of 5 Skidmore Place", In: Art News, 73, Mar. 1974, p. 29-32. 55 Em inglês, 'us' pode significar tanto os pronomes 'nosso' ou 'conosco', como ser a abreviação de Estados Unidos [United States] [Nota da Tradução].

56 O'Hara faz uma corruptela da expressão "fathers of our country" [os pais da nação] com a gíria farter [peidão].

57 Sidney Tillin, Arts Magazine, 34 [dez. 1959], 62.

58 Ver Everybody's Autobiography, de Gertrude Stein [STEIN, 1973, p. 15].

59 Em entrevista a Lucie-Smith, O'Hara sugere que sua única verdadeira colaboração foi Stones [O'HARA, 1975, p. 4]. Com razão, ele pontua que seu trabalho com pintores como Mike Goldberg e Graça Hartigan não se tratava de uma colaboração, pois eles utilizavam seus poemas. Mas ele parece ter esquecido Poemapinturas, fruto do verdadeiro esforço colaborativo de dois artistas trabalhando simultaneamente. 
60 Notas do catálogo da exposição Poemapinturas realizada no Loeb Student Center da Universidade de Nova York de 9 de janeiro a 5 de fevereiro de 1967.

61 PERREAUlT, John. Art News, v. 65, 1967, p. 11.

62 Entrevista com Norman Bluhm realizada em 2 de dezembro. de 1975, em Nova York.

63 Conforme artigo publicado na revista Art News, 65, fev. 1967, p. 11

64 A série de quadrinhos criada por O'Hara e John Brainard foi originalmente desenvolvida para o portfólio de arte canadense C Comics [1964-65]. Uma série desses quadrinhos é reproduzida na revista Panjandrum, 2 \& 3 [1973].

65 Um exemplo semelhante pode ser encontrado no trabalho de Franz Kline. Kline tomou o poema de "Eu sempre vou te amar..." escrito em 1957, e o incorporou à caligrafia do próprio $O^{\prime} H a r a$ em uma gravura feita para o portfólio 21 Gravuras e Poemas, publicado pela Galeria Morris em 1960. Para mais, conferir as Notas aos Collected Poems [O'HARA, 1971], p. 539.

66 Poets and Painters and Painters and Poets, artigo publicado no jornal The New York Times, 11 de agosto de 1968, Seção II, p. 24.

67 Cf. Notas ao catálogo de Poempaintings, por Bill Berkson.

68 Carta não publicada de O'Hara para Gregory Corso, 15 de março de 1958. 


\section{REFERÊNCIAS BIBLIOGRÁFICAS}

APOLLINAIRE, Guillaume. Apollinaire on Art, Essays and Reviews 1901-1918, Coleção The Documents of 20th Century Art. Nova York: Viking, 1971, p. xxix.

BRAINARD, Joe et al. Panjandrum: A Journal of Contemporary Poetry 2 \& 3 [1973] - Double Issue with Special Supplement on Frank O'Hara. San Francisco: Panjandrum Press, 1973.

MOTHERWELL, Robert [org.]. The Dada Painters and Poets, An Anthology, tradução de Ralph Manheim. Nova York: Wittenborn, Schultz, Inc., 1951.

O'HARA, Frank. In Memory of My Feelings. A Selection of Poems by Frank O'Hara. Nova York: Museu de Arte Moderna, 1967.

O'HARA, Frank. The Collected Poems of Frank O'Hara. Nova York: Knopf, 1971.

O'HARA, Frank. Art Chronicles 1954-1966. Nova York: Braziller, 1975a.

O'HARA, Frank. Standing Still and Walking in New York. Bolinas, California: Grey Fox Press, 1975b.

O'HARA, Frank. Meu coração está no bolso. Tradução de Beatriz Bastos e Paulo Henriques Britto. São Paulo: Luna Parque, 2017.

PERREAULT, John. Art News, v. 65, 1967.

PERLOFF, Marjorie. Poet among Painters. Nova York: Braziller, 1977.

RIVERS, Larry. Location: Spring 1963. Nova York: Longview Foundation, 1963.

RUBIN, William S. Dada, Surrealism and their Heritage. Nova York: Museu de Arte Moderna, 1967.

TOMPKINS, Calvin. The Skin of the Stone. In: The Scene, Reports on Post-Modern Art. Nova York: Viking, 1976.

LIPPARD, Lucy. Max Ernst: Passed and Pressing Tensions, Hudson Review, 23, inverno 1970-1971.

TILLIN, Sidney. Arts Magazine, v. 34, dez. 1959.

STEIN, Gertrude. Everybody's Autobiography. Nova York: Vintage, 1973. 